\title{
Rivers of blood: Illustrating violence and virtue in Russia's early modern empire
}

\author{
Raleigh Lecture on History \\ Read 6 November 2014
}

VALERIE A. KIVELSON

Abstract: In the 16th and 17th centuries, between the reign of Ivan the Terrible and that of Peter the Great, Muscovite Russian forces swept eastward, conquering, colonising, and controlling territories reaching from the Volga to the Pacific. Unlike contemporary Western European empires, Russians left few theoretical considerations of what this imperial advance signified to them or how they understood their role as imperial conquerors and overlords. They did, however, leave a colourful collection of illustrated chronicles depicting their battles with the many varied peoples of the steppe and Siberia. Filled with blood and carnage, these images employ surprising visual tropes that distinguish moral from immoral and just from unjust uses of violence, with significant implications for understanding early modern Russian policies of imperial incorporation.

Keywords: early modern Russian, imperial, violence, illustrated chronicles, moral, just, visual tropes.

Violence and empire are inseparable companions. This vicious pairing appears frequently in descriptions of early modern Russia and its tsarist regime. Already in the 16th and early 17th centuries, Western Europeans equated tsardom with arbitrary and unlimited rule and with an emperor distinguished by a 'propensity for violence'. ${ }^{1}$ Russia, to one 17th-century Englishman, was 'Hell-mouth centre, there pitching the Tents of Destruction, there erecting the Thrones of Desolation'. ${ }^{2}$ The specific meanings of broad concepts like violence, however, change over time and depend on their specific context. Violence itself has very different implications, for instance, if inflicted as an act of brutal murder or a heroic act of war. Since violence looms so large in

\footnotetext{
${ }^{1}$ Palmer (1995: 330).

${ }^{2}$ Purchas (1906 edn: 14: 108-9).
} 
accounts of Russia's early modern conquest of its vast Eurasian empire, an analysis of its uses, limits, and interpretations well repays the effort.

Violence did indeed characterise Muscovite society. Arbitrary power was wielded as the prerogative of hierarchy at all levels of society. From the severe exercise of tsarist power to the brutal treatment of serfs on provincial estates, violence accompanied Muscovite authority. Yet, over the last two decades, examinations of practices of court politics, the law, religious and political teaching and gender relations have modified the vision of Muscovy's 'Hell-mouth' tyranny and replaced it with a very different picture. The new model depicts a more consensual relationship between ruler and ruled and a more limited exercise of power, reined in - surprisingly — by moral consensus and Orthodox piety. ${ }^{3}$

This scholarly work has upended centuries of misapprehension about political life in the Russian heartlands, but its reliance on Russian Orthodox Christianity as the cultural glue that held society together renders it difficult to apply to the non-Russian, non-Slavic, non-Orthodox lands of the steppe to the south and east. These areas were contested for centuries between Russians and the nomadic peoples of the steppe. For more than two hundred years, from the early 13th century, Russians paid tribute to their Mongol and Tatar conquerors. From the mid-15th century, following the collapse of the Golden Horde, Muscovites allied and traded with, fought, and ultimately subjugated a variety of polities and nomadic groups left in its wake across Siberia and the Eurasian plain. These peoples were successively conquered and subjugated to tsarist colonial might in the 16th and 17th centuries. Muslim or shamanist, the newly incorporated populations did not share Russia's Orthodox Christian commitments or participate in its long-evolving cultural consensus. So how did Russians make sense of their conflictual encounters with these neighbours? How did violence and virtue, mercy and tyranny play out in the context of imperial wars and rule?

This article examines the stories that Muscovites told themselves about their encounters with the peoples of the frontier, and about modes of rule, the promises and persuasions used by the tsarist regime as it advanced across the Eurasian continent. The study of early modern colonial encounter proves particularly challenging in the Muscovite case, because of deficits in the source base. Muscovites remained largely illiterate throughout this period, and those who mastered and controlled the art of writing generally refrained from committing to paper any abstract, systematic vision of tsarist rule. Doggedly thorough in bureaucratic record keeping, they were profoundly uninterested in what we might call political theory. They rarely do us the favour of telling us what they think or what they make of a situation.

${ }^{3}$ Recent contributions to this revisionist historiography include Gruber (2012); Kivelson (2013); Kollmann (2012); Martin (2012). 
These silences pressure historians to seek out alternative modes of historical investigation, to supplement the recalcitrant textual record. For the question at hand, we are fortunate to have a wealth of images illustrating an idiosyncratic formula of imperial conflict and conquest that balanced high-handed violence and high-minded benevolence. Carnage and bloodshed featured conspicuously in the Russian advance but, at the same time, Russians told themselves stories about the righteousness and justice of their campaigns.

\section{MUSCOVY'S EASTERN EMPIRE: CONQUEST AND CONTROL}

In 1552, Moscow defeated the independent khanate of Kazan on the Volga River, thereby reversing the pattern of previous centuries during which Russians had acknowledged the sovereignty of Mongols and Tatar khans (Fig. 1). Thirty years later, a band of renegade Cossacks led by the famous Yermak Timofeevich crossed the Ural Mountains and began the first campaigns in Siberia. Yermak and his outlaws defeated the troops of the Siberian khan (called tsar in Russian texts), a descendant of the venerated line of Chinggis Khan and ruler of one of several vestigial splinter states left behind after the collapse of the Golden Horde. The Cossacks brought the Siberians under the 'mighty hand' of the Russian tsar and compelled them to pay iasak, that is, tribute in the luxuriant furs that the region produced in abundance. The Cossacks' lucrative success won them the tsar's retroactive blessing, and Yermak governed briefly as the first Russian administrator of the region. By 1637, explorer-adventurers had reached the Pacific, and ten years later, a man named Semen Dezhnev, of whom more later, is credited with the first non-indigenous navigation of the Bering Straits, anticipating Bering's 'discovery' by 80 years. En route across the continent, the Russians encountered and battled or cowed a variety of peoples into submission: Samoyeds and Kalmyks, Mongols and Tatars, and various Artic reindeer herders and dogsledders. ${ }^{4}$

\section{DOCUMENTING VIOLENCE: ILLUSTRATED HISTORICAL CHRONICLES}

In chronicling their encounters in the steppe, Muscovite authors and artists made no effort to mask or obscure the horrors of imperial aggression. Illustrated histories paint a vivid picture of warfare, brutality, and bloodshed.

${ }^{4}$ On the history of Siberia, see among others Dmytryshyn et al. (1985); Lantzeff (1943); Lincoln (1994); Slezkine (1996); Wood (1991). 


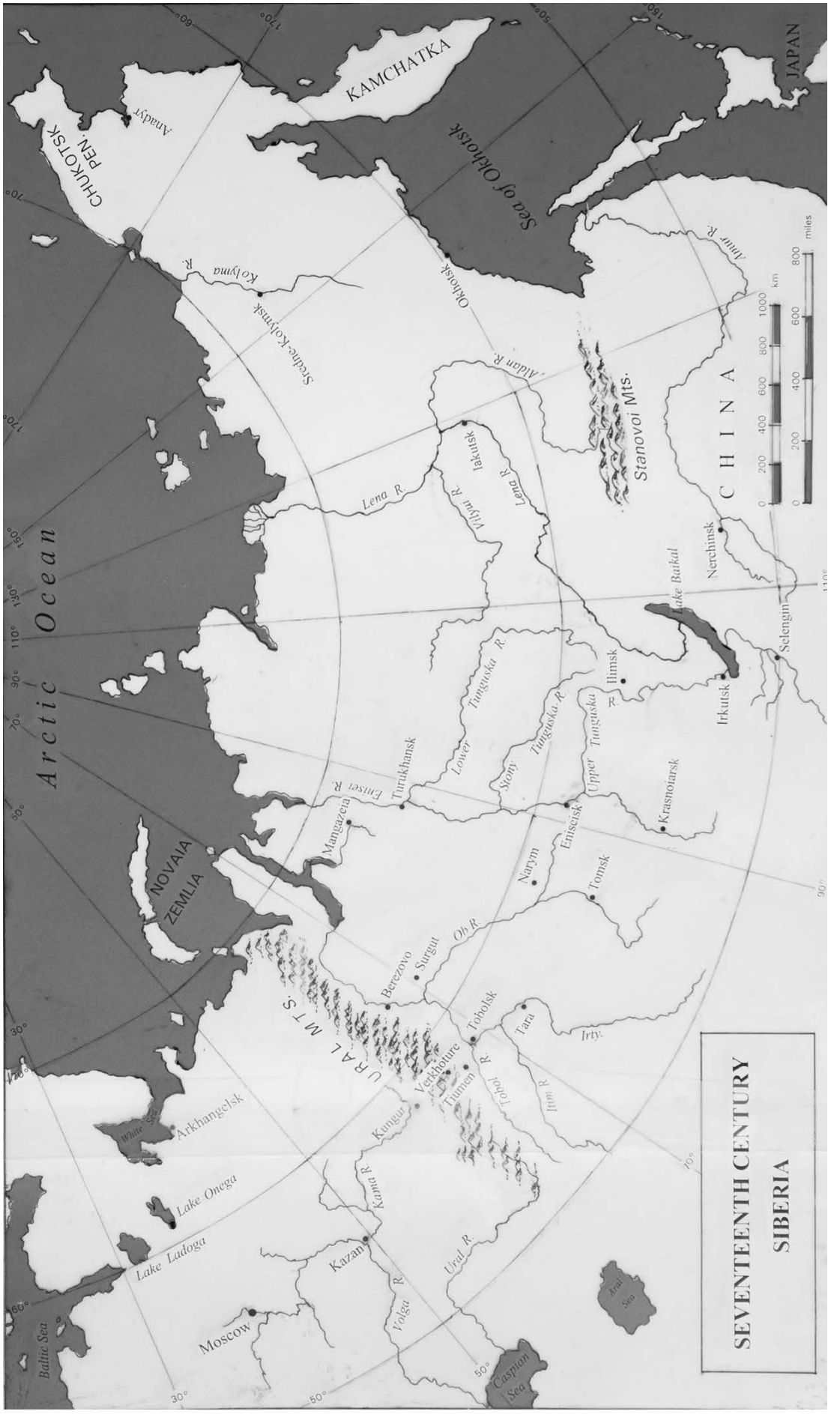

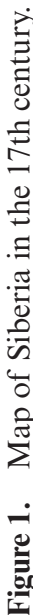


Two remarkable corpuses of visual records document Muscovite imperial advance. First, there is the amazing Litsevoi letopisny svod, or illustrated historical chronicle. The Litsevoi svod was the massive and mysterious undertaking of the court of Ivan the Terrible, created in the 1560 s and 1570 s. The compilation consists of over 10,000 folios and more than 16,000 illustrations. Why this monster project was commissioned remains unclear, although many theories have been floated. It sat in a single copy, a huge pile of manuscript pages, unbound until the 19th century, and unpublished until a glorious, full-color, 38-volume facsimile edition hit the scene in 2011 and sent waves of excitement through the scholarly community. ${ }^{5}$ This publication inspires and makes possible a visual study such as this one.

The chronicle covers all of history from Creation and biblical times, through 'world history', to the history of Russia, up through the conquest of Kazan, arguably Russia's first truly imperial conquest. The hand-drawn illustrations are fully coloured except in the last sections, those most relevant for our purposes, where the images were beautifully drawn in ink but for the most part not filled in.

Similar visual conventions were still in use over a century later when our second collection of sources was put together. Unlike the Litsevoi svod, compiled by a vast team of official chroniclers, scribes, and artists in the heart of the Kremlin, this corpus was penned by one man, assisted by his sons and nephew, far from the heart of power, and largely at his own volition rather than in response to official orders. This was the work of Semyon Ulianovich Remezov, self-taught icon painter, cartographer, ethnographer, and historian, who lived and worked in Tobolsk, in Western Siberia, from the late 1680s to around 1720. Taking his narrative from an earlier text, Remezov produced a densely illustrated history of Siberia, primarily documenting Yermak's campaign. ${ }^{6}$

Taken together this visual/textual corpus tells us that, at one level, war had its own ineluctable logic and justification, and needed no apologies. Of the 16,000 hand-drawn and colourfully painted illustrations of the Litsevoi svod, many thousands depict clashing armies. Scene after nearly identical scene shows impassive or even slightly smiling figures massing against each other, shooting, hacking, piercing, exploding, burning, decapitating, or generally demolishing the other side (Fig. 2).

Some violence, however, is shown as righteous and fully justifiable; other acts as unsanctioned and illegitimate. This does not seem to rest on a code of manly gallantry or devotion to the protection of the weak and defenceless as one might expect. A page dedicated to the assault on the fortified city of Kazan conveys this rather surprising absence. The text announces, 'The Orthodox troops approached the khan's court and mercilessly (neshchadno) slashed the lowly (nechestivye) men and women. Rivers of

\footnotetext{
${ }^{5}$ Kazakova et al. (2009-14).

${ }^{6}$ Remezov (1880 edn); Armstrong (1975); Gol'denberg (1965, 1991).
} 


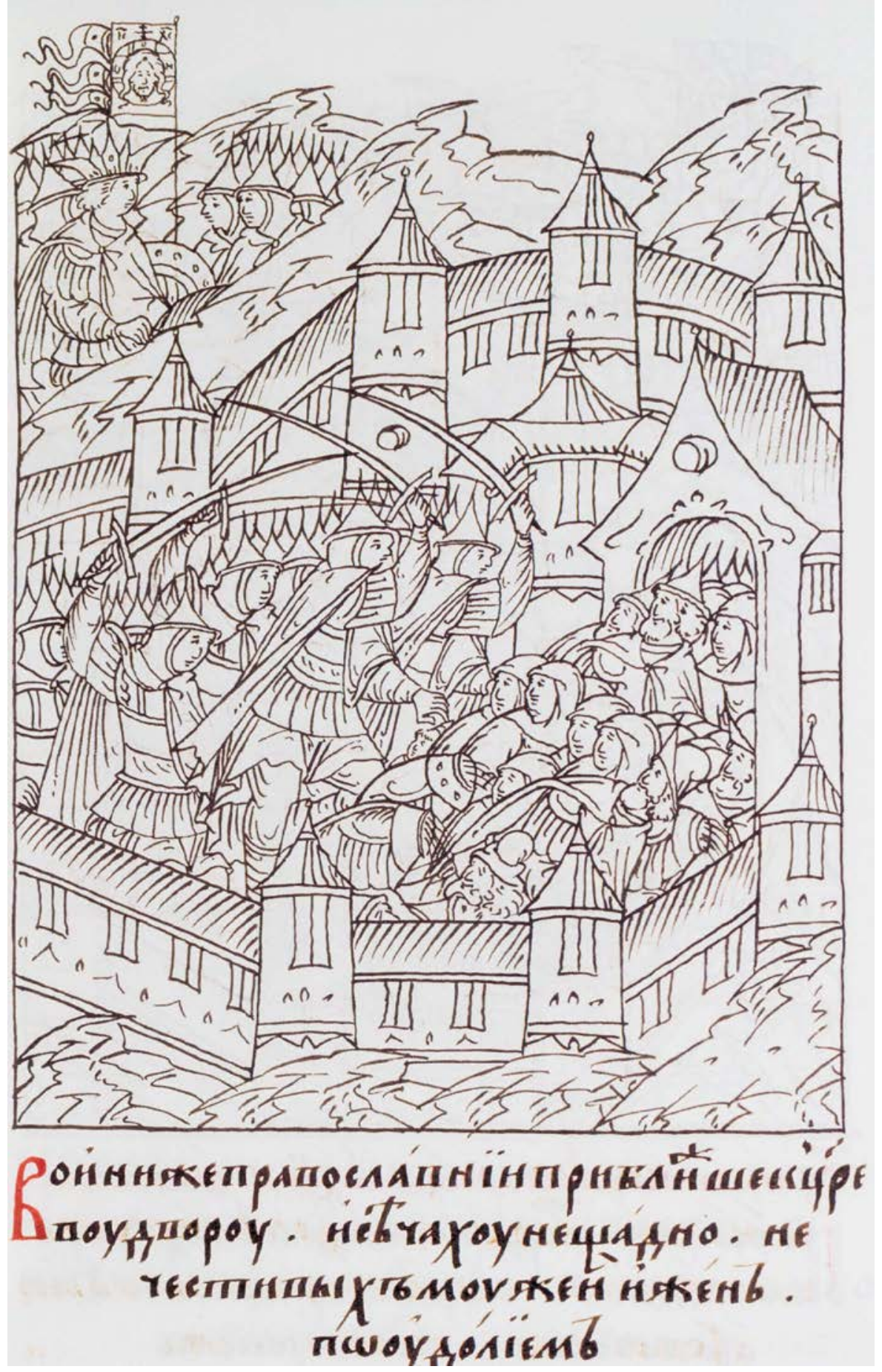

Figure 2. Muscovite troops attack the lowly men and women of Kazan. Kazakova et al. (2011): 21: 438. 
blood ran through the valleys.' ${ }^{77}$ The illustration of the scene reinforces the message. A panicked crowd of women and old men cower in terror before the onslaught of slashing Russian swords. Looking back over their shoulders, they beseech their attackers for mercy but receive none. Severed necks spurt streams of blood, and decapitated heads close their eyes in death. If we look still more closely, we see a child among the victims, also looking back at the rampaging swordsmen, hoping for pity that will not come. ${ }^{8}$

The trope of righteous mercilessness reverberates in Remezov's narrative as well. Describing a battle between Cossacks and Tatars, he writes that his protagonists 'fought mercilessly hand to hand, slashing one another, so that horses were up to their bellies in the blood and corpses of the unbelievers'. The associated illustration does not stint in depicting the cascades of blood gushing from the tangle of corpses, human and equine (Fig. 3). ${ }^{9}$

The shameless, indeed celebratory revelling in merciless slaughter reflects more than a vicious streak in Russian chronicles. In Muscovite legal writing, 'merciless' turns out to be a term of art, a quality to be lauded and even required in the pursuit of righteousness. Orders from the Moscow authorities to governors in the provinces demanded that they conduct investigations 'mercilessly' and interrogate and torture suspects 'mercilessly', so as to find the truth and bring the guilty to punishment. ${ }^{10}$ The conviction that justice had to be administered harshly, without leniency, was so broadly shared that mid-17th-century protesters complained about the overly sympathetic treatment of the guilty in the tsar's courts. Their petitions criticised their tooforgiving tsar for letting ill-doers go unpunished. ${ }^{11}$ It was his God-given duty to punish the guilty, a duty he could not shirk. The ruthless assault on the old men, women, and children of Kazan could be relished in good conscience by the scribes and painters of the Litsevoi svod, because true justice had to be administered sternly, without favouritism, doubt, or weakness.

\footnotetext{
${ }^{7}$ Kazakova et al. (2011: 21: 438).

${ }^{8}$ As discussed below, the moral valence of these scenes depends on who commits the acts of violence. In an earlier volume the artists used almost exactly the same image to depict the inhumanity of the assault of 'godless Tatars' on men, women, and children. The illustration shows a crowd of townspeople cowering in just the same posture as in the Kazan scene, but a woman holds a naked child in her arms. Kazakova et al. (2014: 5: 318).

${ }^{9}$ Remezov (1880 edn); Armstrong (1975: chap. 43).

${ }^{10}$ See Kollmann (2012, passim); Kivelson (2013: 198-232); Michels (2003: 515-42). But see discussion of Muscovites' insistence on mercy below.

${ }^{11}$ 'Nakaz Vladimirtsev vybrannomu imi iz svoei sredy dvorianinu . . .' (28 June 1648), Sankt-Peterburgskii Institut Istorii (SPbII RAN) [St Petersburg Institute of History of the Russian Academy of Science, St Petersburg], sobranie A.M. Artem'eva, no. 2.
} 


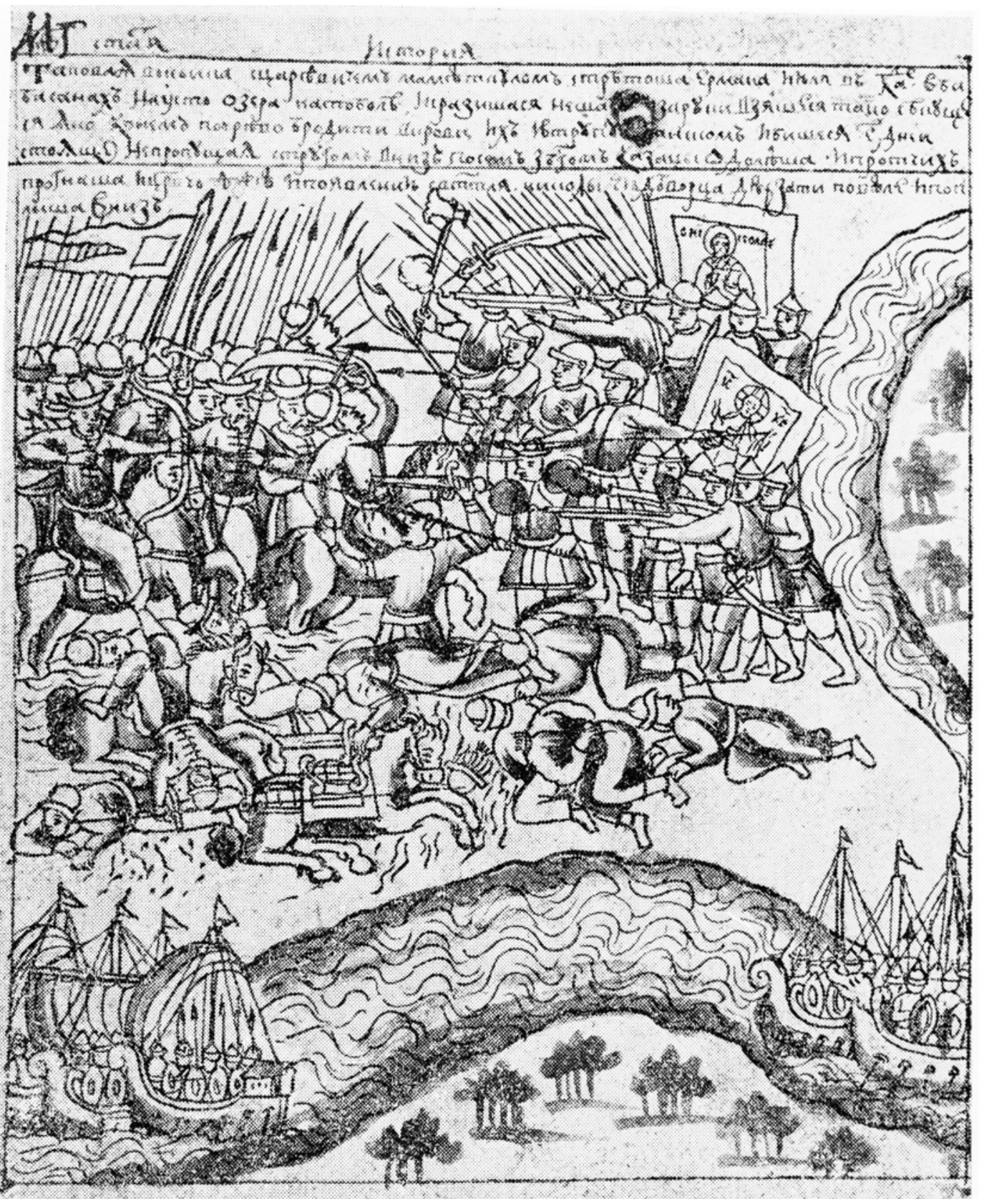

Figure 3. Cossacks battle the troops of Kuchyum, khan of Siberia. Remezov (1880 edn), ch. 43. 


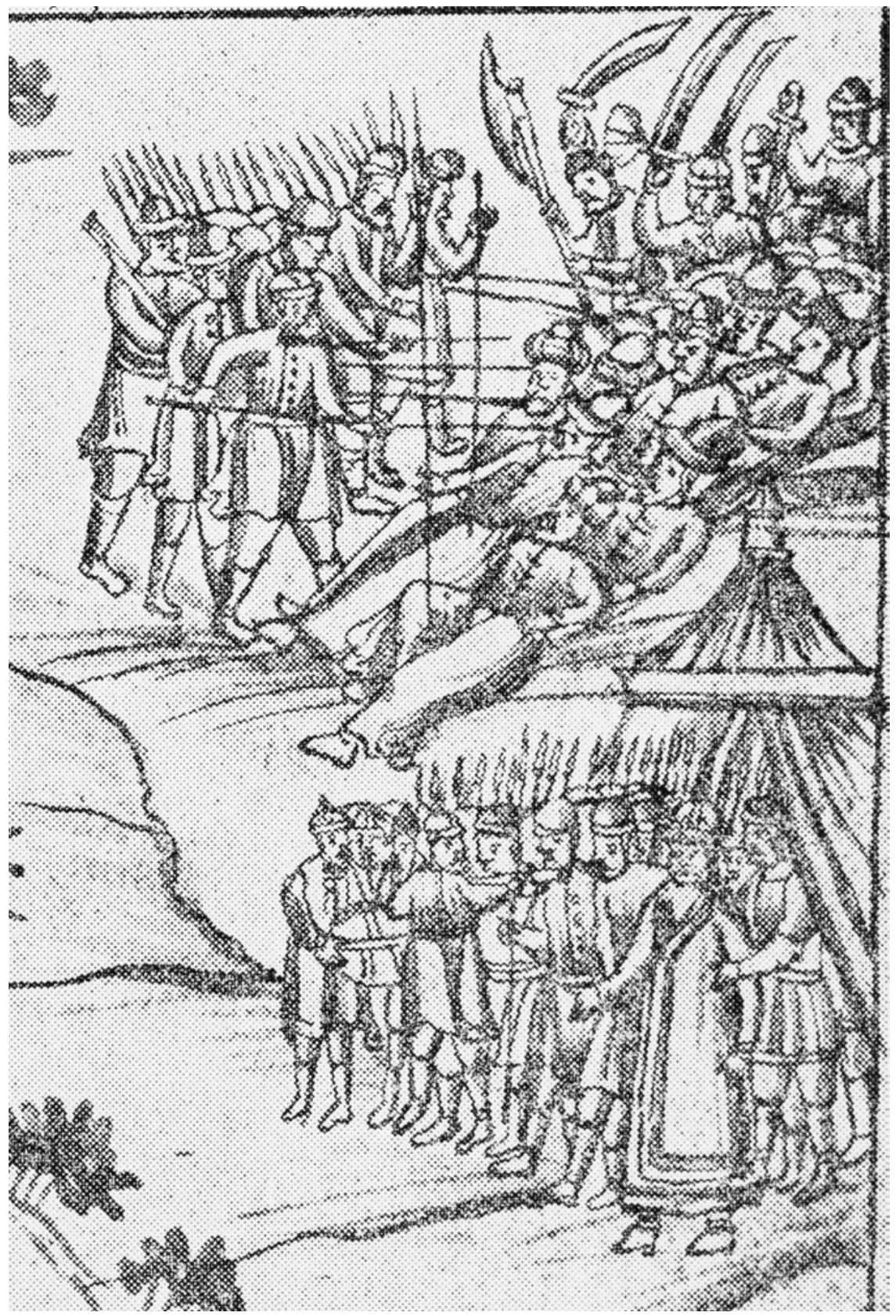

Figure 4. Cossacks attack sleeping Tatars. Remezov (1880 edn), ch. 87. 
Also somewhat surprising is the way that actions that in more chivalric frameworks might be seen as underhanded or even cowardly sneak attacks are presented without the slightest discomfort. ${ }^{12}$ For instance, Remezov tells us that 'Yermak sent sixty able fighting men who, on reaching Kularovo, fell on [a group of] sleeping men. They slew a great number of pagans and took the khan's heir alive in his tent, returning to Yermak in the city, laden with rich booty' (Fig. 4). No word of censure and no shade of disapproval colours the text. With the same equanimity, the illustration depicts the Tatars peacefully sleeping in a heap, and the captured prince emerging from his tent, hands expressing his sleepy bewilderment. ${ }^{13}$

\section{TSARIST JUSTICE AND VIRTUOUS VIOLENCE}

So on what basis, if at all, did Muscovites differentiate moral from immoral or just from unjust uses of violence? Where slaughtering women, children, old men, and sleeping foes elicits no discomfort, it is hard to imagine what might constitute excessive or immoral use of violence. Occasionally the inclusion of some kind of supernatural presence directs the viewer's assessment of good or evil. When Archangel Michael, or haloed angels wielding swords of fire, or a great apparition of 'Lord Jesus Christ Our Beautiful King' appears in an illustration, the artist leaves no room for uncertainty about where virtue resides or which regiments kill in God's name. The morality inscribed in other scenes of massacre is harder to parse. However, once we unlock Muscovite visual codes, we can see into the finer gradations of moral judgement.

Here I build on important insights reached by Nancy Shields Kollmann in her recent work on punishment in the Litsevoi svod. Kollmann examines the chronicle's depictions of executions that took place not in colonial or frontier contexts, but in the heart of Moscow, under the aegis of the Kremlin. She finds that the chronicle illustrators, using highly conventionalised scenarios, rigorously differentiated legitimate from illegitimate applications of violence. She writes, 'Although one's eye might instinctively move to the suffering body of the condemned in these images, the narrative focus was intended to be the ruler in judgment.. ${ }^{14}$ The ruler is bedecked with regalia and his elevated status marked by conventional symbols of authority. He wears the headdress appropriate to his office: a rounded hat if he serves as grand prince or the

\footnotetext{
${ }^{12}$ This is not just a modern response. Chivalric codes and more early modern gentlemanly conduct were in circulation in Europe at the time and earlier, and murdering sleeping men would have been viewed as ungentlemanly. Sneaky characters like Iago or Claudius might murder men in their sleep, but heroes would not.

${ }^{13}$ Remezov (1880 edn); Armstrong (1975: chaps 78, 87). See also chap. 95.

${ }^{14}$ Kollmann (forthcoming).
} 
pointed crown that identifies a tsar. He sits on an elegant throne and rests on a sausageshaped pillow, the same that conventionally appears in Orthodox iconography on the throne of Christ in Majesty. ${ }^{15}$

'To render a verdict', Kollmann continues, 'the ruler uses the specific and relatively rare (in iconography in general) gesture of pointing, ordering a group of men (boyars) to carry out his verdict or order (Fig. 5). In turn, those who were sent to carry out the verdict stand alongside or behind the executioner to symbolise the ruler's justice. They in turn often point (sometimes they simply gesture) to authorise the punishment; their presence symbolises the legitimacy of grand-princely judgement. ${ }^{16}$

Further, legitimate judgement was usually rendered in consultation with advisers. Their full and frank discussion is represented here by open palms, extended in conversation. After the facts have been aired and official judgement rendered, appropriate punishment is soberly meted out. The condemned are allowed a modicum of dignity in their final moments. Where they may be shirtless as they receive the lashes of the knout, they rarely are stripped beyond what is necessary, and most commonly are shown fully clothed.

Kollmann remarks that unauthorised violence was visibly marked in the chronicle by the absence of precisely these indicators, and was singled out for disapprobation. Violence carried out without explicit orders from the tsar, without collective discussion, and without an officially authorised tsarist official at the site to confirm the tsar's order violated expectations of righteous justice. Untoward violence is often indicated visually by the absence of the tsar, or by an excess of violence and degradation, as in the vulnerable nakedness of the unfortunate boyar Vorontsov, stripped naked, driven out of the Kremlin, and beaten by rivals at court (Fig. 6). ${ }^{17}$ The illustrators, reflecting legal norms that they evidently understood well, conveyed fine distinctions in evaluations of just or abusive violence through precise, consistent visual codes.

This is an important finding, both in the domestic context of the Muscovite court, where Kollmann has identified it, and in the frontier context of imperial advance. Why is it so important? With its pictorial insistence on legality, consultative justice, measured punishment, and the dignity of the condemned, the illustrated chronicle dispels a widely held impression that throughout its unhappy history, Russia lacked legal consciousness and failed to develop a sense of law as formal, fair, and just. ${ }^{18}$ Our illustrators wordlessly urge us to set those stereotypes aside and take seriously Muscovite insistence on formal, legal justice. The fact that Kollmann draws on visual rather than

\footnotetext{
${ }^{15}$ Kollmann (forthcoming). For examples see Popov (1993). With thanks to Michael Flier for pointing out this source of the pillow.

${ }^{16}$ Kollmann (forthcoming); Kazakova et al. (2011: 20: 98).

${ }^{17}$ Kollmann (forthcoming); Kazakova et al. (2011: 20: 326).

${ }^{18}$ Arnold (2014); Burbank (2004); Kollmann (2012); Weickardt (1992); Wortman (1976).
} 


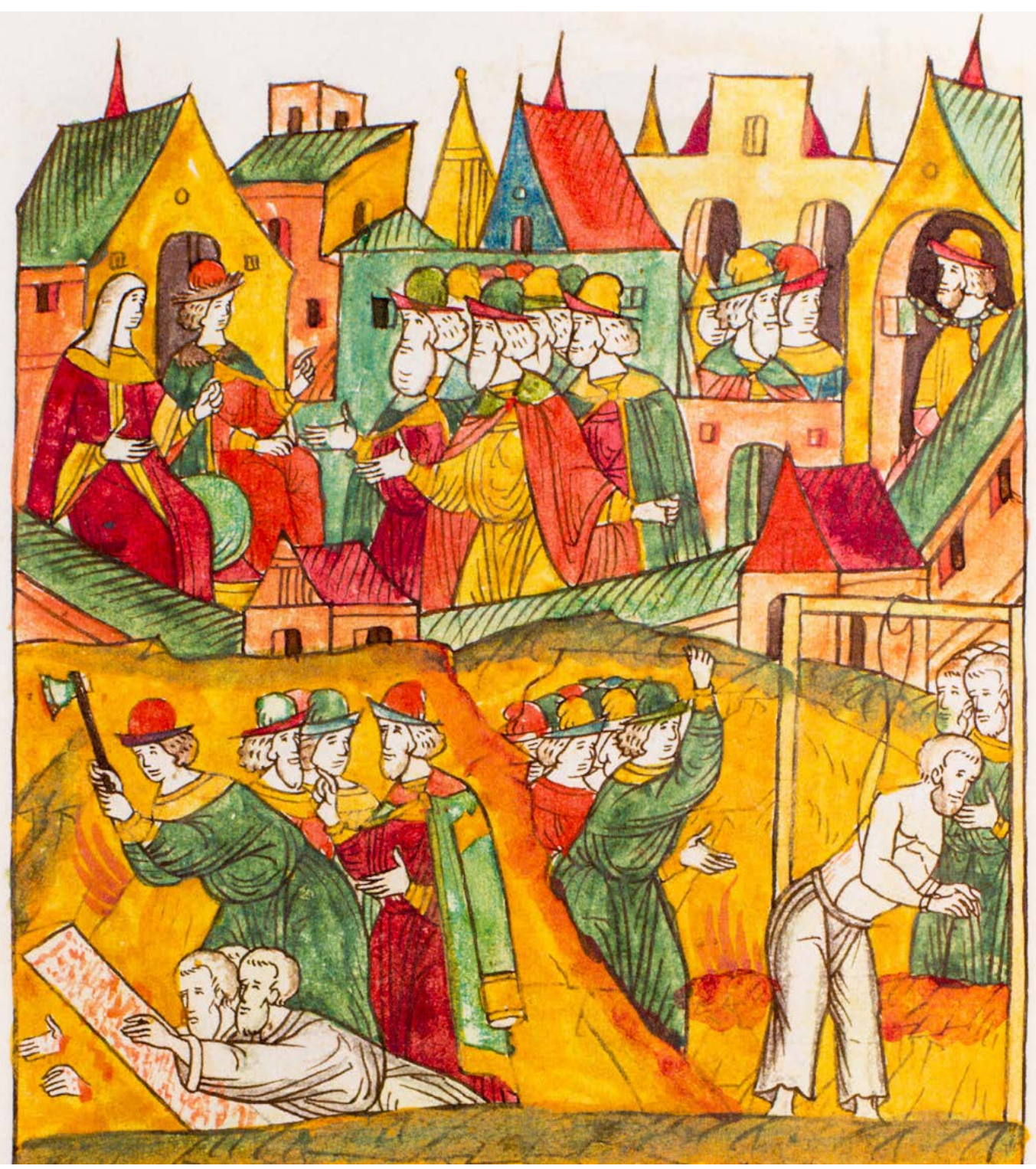

Figure 5. Grand Prince Ivan Vasilevich and his mother authorise executions. Kazakova et al. (2011), 20: 98 .

textual sources-for frequently there is no echo of the particular visual tropes in the accompanying chronicle text-lends force to the conclusion that the systematic representation of justice in these ways stemmed not from the dictates of the text but rather from widely accepted notions of what constituted legal and moral best practices.

If we apply Kollmann's findings to the frontier of empire, we find startlingly consistent application. The chronicles treat us to similar depictions of formal judgement 


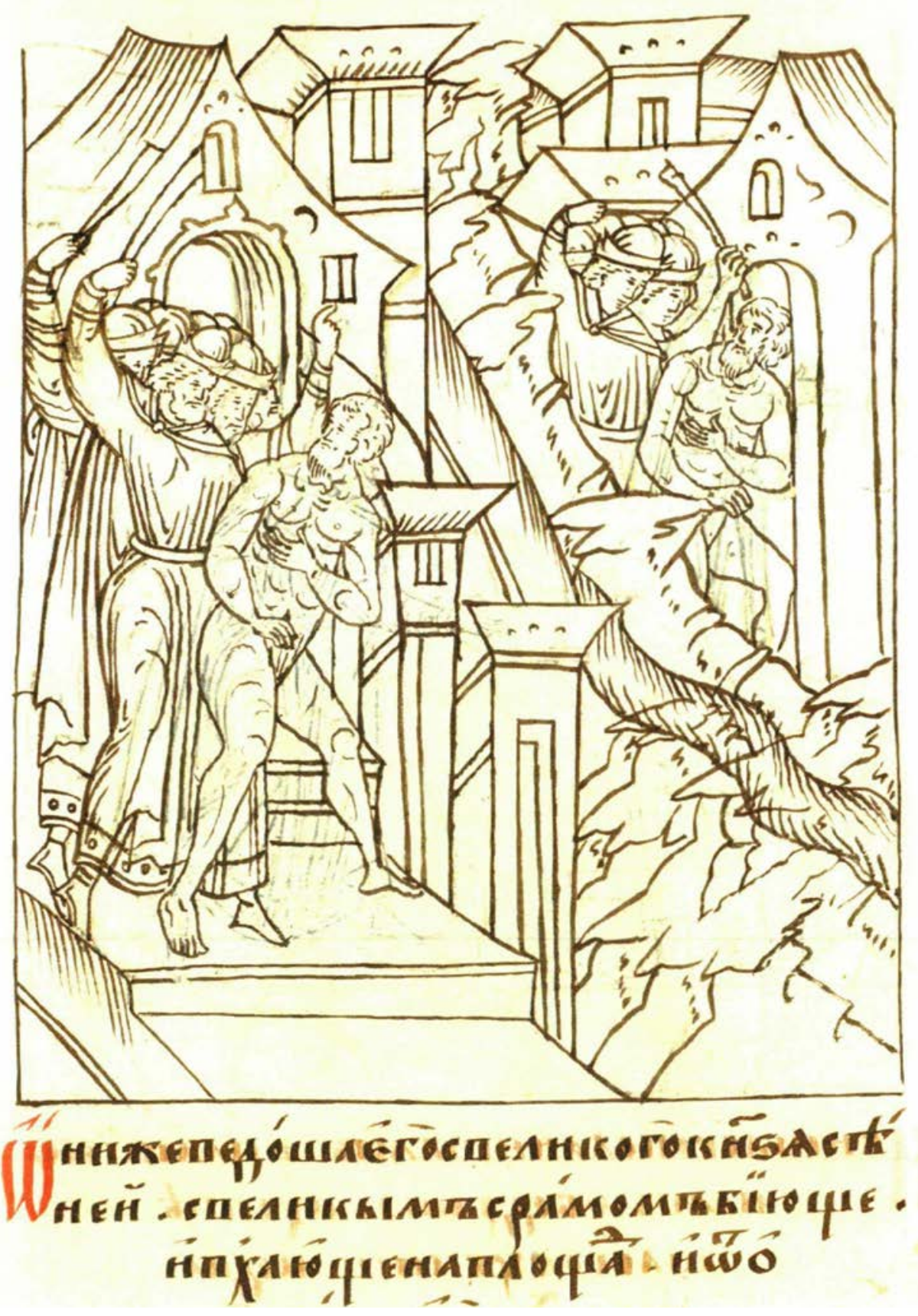

Figure 6. Boyars carry out an attack on Vorontsov without authorisation. Kazakova et al. (2011), 20: 326. 
rendered in consultation with worthy advisers and enacted by deliberately authorised verdict with a pointed finger. In an image from the Litsevoi svod, Ivan IV raises a finger to authorise an assault on Kazan (Fig. 7). In Remezov's chronicle, since the battle for Siberia was a freebooter operation carried out against the tsar's command, the visual focus could not be on the tsar and his august decision-making authority. Instead, both the verbal narrative and the accompanying illustrations centre on Yermak, the tsar's (admittedly self-appointed) stand-in. Throughout the account, Yermak consults in free and open, comradely fashion with his band of Cossack brothers. For instance, when the Cossack band reaches a decision to winter on the Tura 'because they had seen multitudes of pagans and dared not sail to Tobol'sk', ${ }^{19}$ Yermak is shown in animated discussion with a cluster of fully armed comrades. Acknowledging the Cossack leader's lofty position and moral weight, Remezov displays a regal pillow on

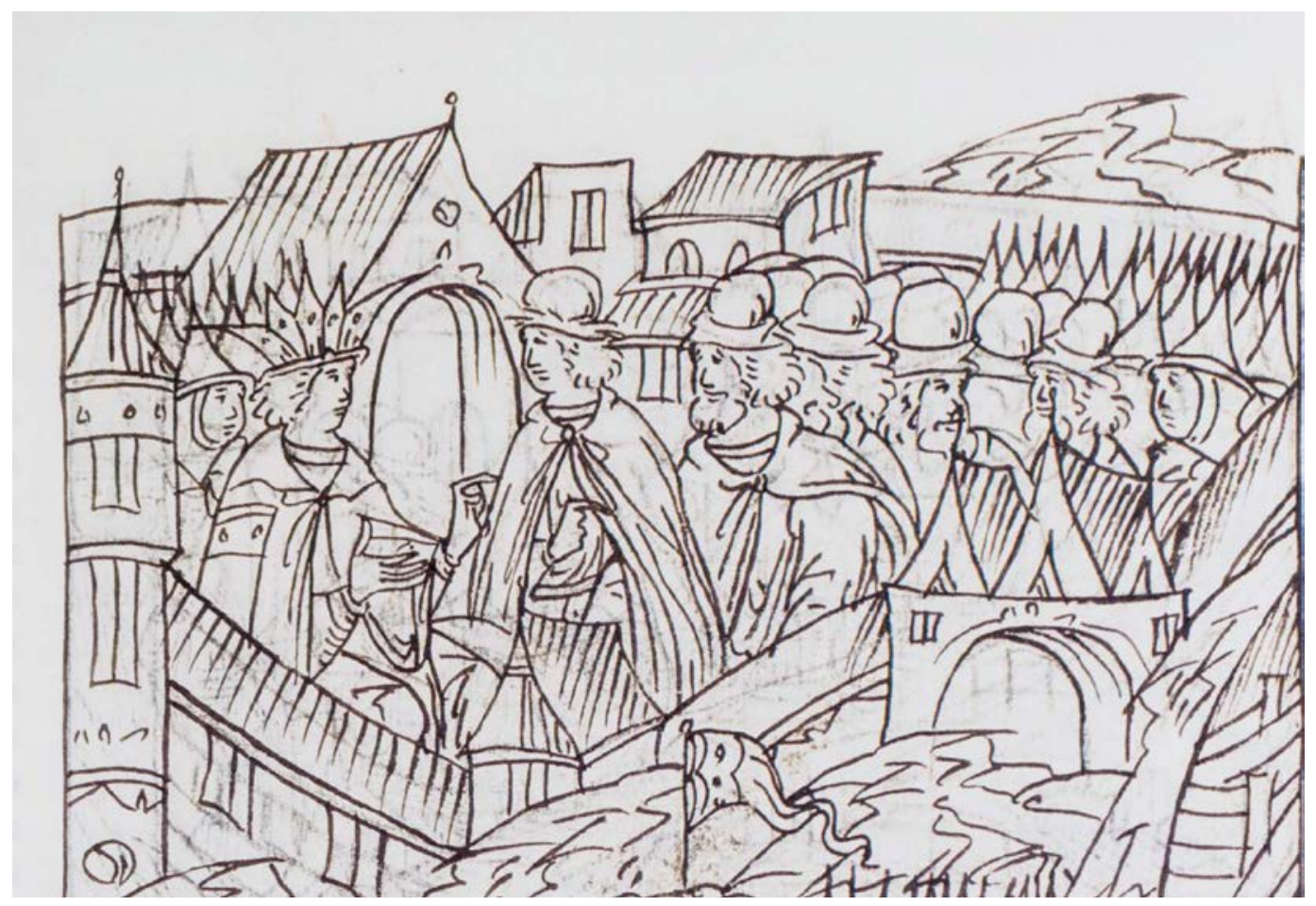

Figure 7. Ivan authorises the attack on Kazan. Kazakova et al. (2011), 21: 474.

${ }^{19}$ Remezov (1880 edn); Armstrong (1975: chap. 15). 
Yermak's throne-like chair (Fig. 8). Like the tsar in the Kremlin, the leader is idealised as simultaneously a lofty imperial presence and an accessible, consultative leader. Hands raised, palms open, Yermak gesticulates to signify interactive exchange of ideas. His conversation with a kneeling bearded adviser is equally dynamic when he considers the option of a full-bore retreat after a devastating battle. ${ }^{20}$ And he consults with 'his like-minded company' before writing a letter to tsar Ivan, begging for his blessing on their successful enterprise. ${ }^{21}$ The precise wording of this supplication for the tsar's favour is exceptionally important for the Cossack bandit-adventurers, since their future in the tsardom depends entirely on it. In Remezov's cartoon-like drawing Yermak dictates while the scribe writes down his words, but the co-authorship of the entire knot of men is palpable. Clustered tightly, intently leaning forward, they signal their participation with forceful hand gestures. One man in the crowd proposes his suggestions with a vehemence conveyed in the way he hunches toward the table. The picture effectively conveys the urgent collectivity of the process (Fig. 9).

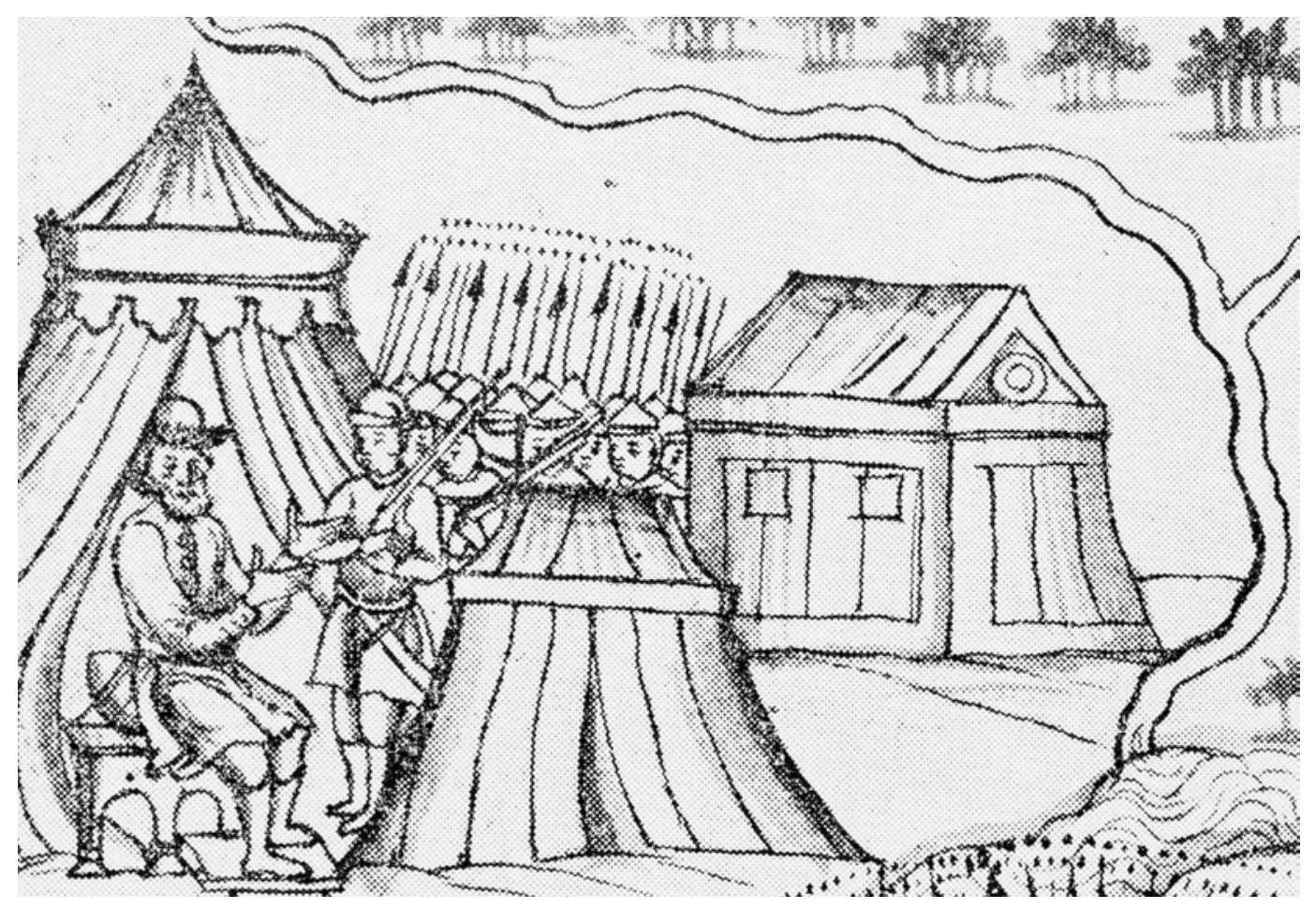

Figure 8. Yermak and his men discuss strategy. Remezov (1880 edn), ch. 15.

${ }^{20}$ Remezov (1880 edn); Armstrong (1975: chap. 39).

${ }^{21}$ Remezov (1880 edn); Armstrong (1975: chap. 84). 


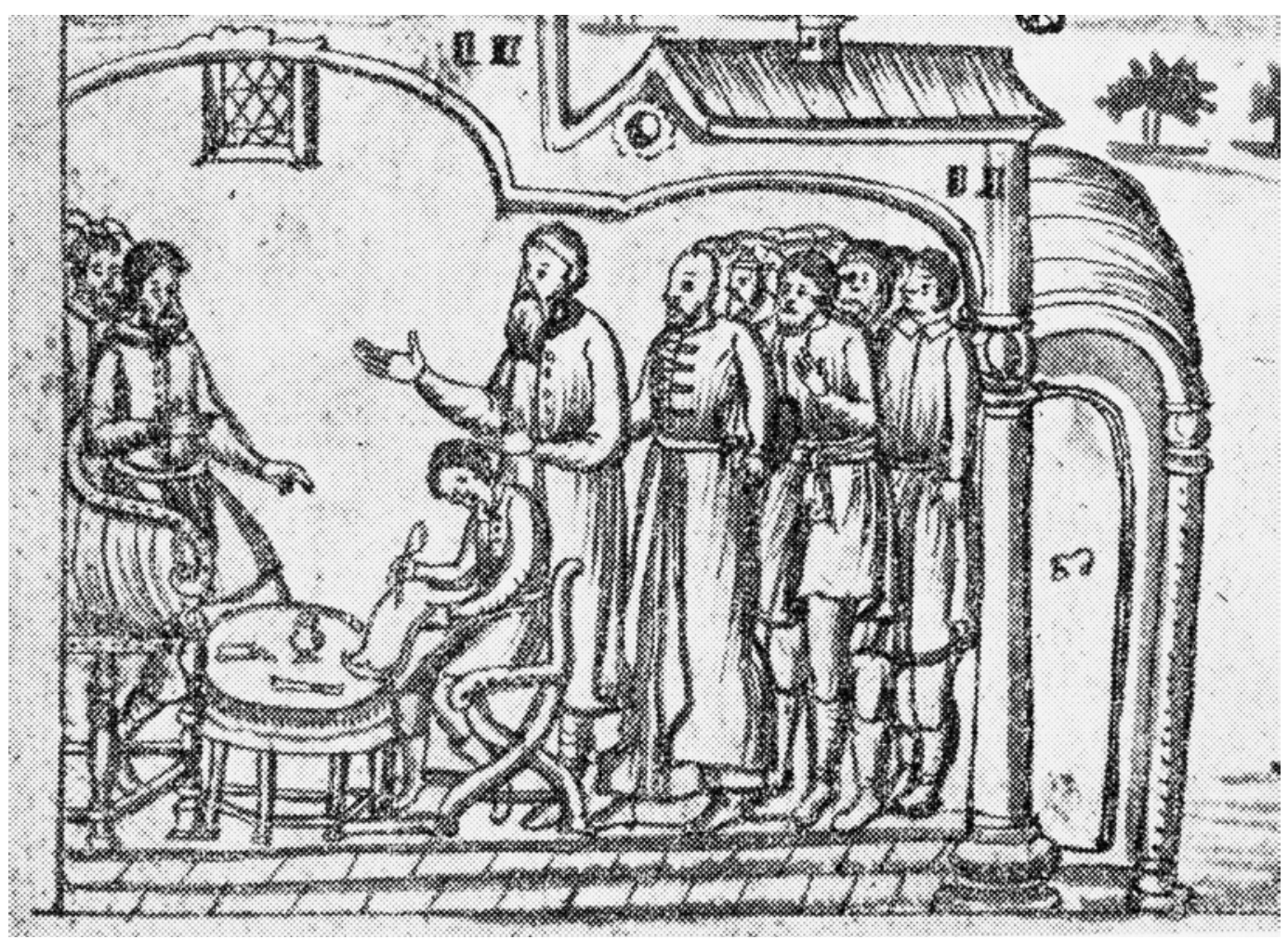

Figure 9. Yermak and his men compose a letter to the tsar. Remezov (1880 edn), ch. 84.

\section{LEGITIMACY AND TYRANNY ON THE STEPPE: DEPICTIONS OF TATAR RULE}

Given that our sources illustrate Russian views of virtuous governance, the aureole of virtue that marks the tsar's authority is not surprising. More unexpected is the generosity with which the same miniaturists invested their Mongol-Tatar foe with the same trappings of legitimate rule. In the many volumes of the Litsevoi svod devoted to clashes with the Mongols, the illustrators scrupulously identify the reigning khan (tsar or emperor, in the text) with an unmistakable pointed crown, a stable attribute of legitimate imperial rule. Russian princes appear in the same pages without crowns. Instead they wear rounded caps with fur rims, as appropriate to their actual status. Russian rulers did not formally claim the imperial title of tsar until the coronation of Ivan IV (the Terrible) in 1547, and the chroniclers duly signalled that distinction, recognising the steppe rulers from the imperial lineage of Chinggis Khan as outranking the Rus princes and as legitimately reigning emperors, despite their role as opponents 
of Rus in the narration of the text. What's more, their attacks on Orthodox Rus are frequently granted the same legitimacy as righteous tsarist action. The terrible 'godless' Khan Baty, for instance, is depicted unleashing his armies against the city of Riazan with considerable grandeur and poise. Like his Muscovite counterparts he signals consultation with advisers with a raised hand, palm open. Surveying the scene from his throne, he points to a solemn, bearded attendant to authorise the attack. The attendant himself then dutifully points his finger, conveying the official order to the troops. The resultant carnage occupies the bottom right-hand corner of the page, where the khan's troops put the town to the torch, brightening the scene with tongues of flame that blend with the lines of blood gushing from the cowering townspeople (Fig. 10). ${ }^{22}$

These visual indicators of imperial legitimacy and formal justice even accompany pictures of Mongol khans as they enact their most heinous acts, including the martyrdom of saintly Rus princes. In a depiction of the martyrdom of Prince Michael of Chernigov, Khan Baty perches grandly on his royal throne, his leg bent up confidently, his imperial bottom resting on the pillow of empire, the same as we have noted in the Kremlin scenes. With an authoritatively crooked finger, he signals that Prince Michael should be executed. Surprisingly, the scene appears to replicate the cues signifying legitimate, authorised punishment. Only when our eye travels to the bottom of the page do we see that this apparently judicious sentencing fails the test of rigorous justice. The saintly martyr has been callously stripped to his trousers (and halo), and the murderer's knife, rather than a more seemly instrument of execution, points at his vulnerably exposed throat. Wavy curtains of blood emanate from the saint's brutalised corpse. ${ }^{23}$ While the Muscovite miniaturists grant their Mongol overlord the legitimate insignia of imperial office and even allow that his sentencing is carried out according to due process, the villainy of the affair is made evident in the display of unnecessary humiliation (Fig. 11).

Shifting forward to Remezov's late-17th-century Siberian chronicle, we find the same visual vocabulary at work, again used to underscore the sharp contrasts between Russian justice and its subversion in the Tatar camp. Remezov's sketches acknowledge Tsar Kuchyum's legitimate status as heir to a fragmentary vestige of the Chinggisid empire, while simultaneously undercutting that legitimacy by showing how his justice goes awry (Fig. 12). Kuchyum wears his pointy crown of imperial legitimacy, and sits on the stately pillow of office, but the implications here are entirely different. The text sets the scene, explicitly listing Kuchyum's offensive practices:

\footnotetext{
${ }^{22}$ Kazakova et al. (2014: 5: 327; also 330).

${ }^{23}$ Kazakova et al. (2014: 6: 97).
} 


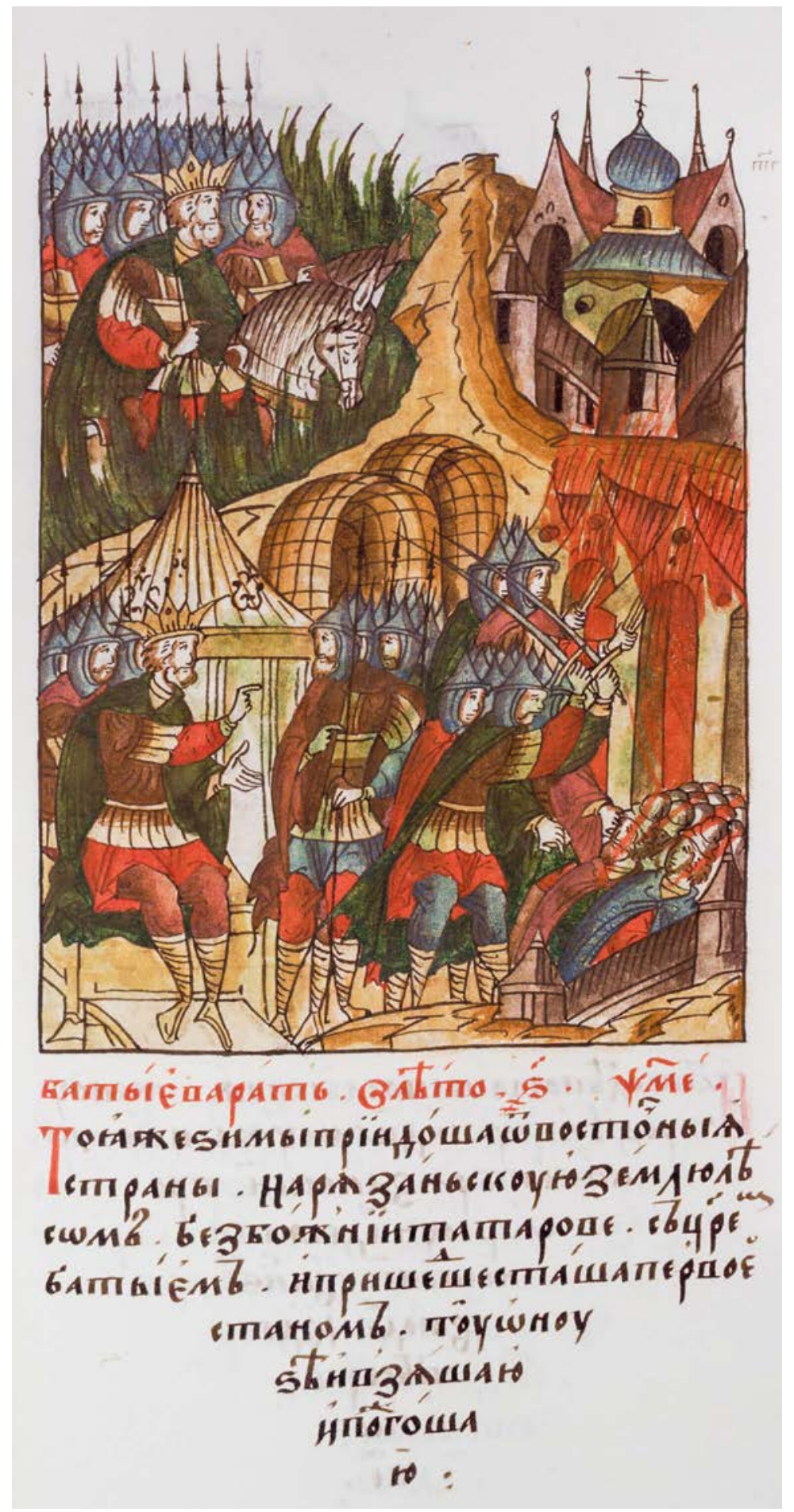

Figure 10. Khan Baty orders attack on Riazan. Kazakova et al. (2014), 5: 327. 
Kuchyum was of the infidel faith, worshipping idols and eating unclean foods. He led a sinful life for he had 100 wives, and youths as well as maidens, which is also permissible to the other infidels in whatever number they desire. But God the all-seeing soon put an end to his reign. ${ }^{24}$

Interestingly, the text emphasises God's visual acumen. In the delightful accompanying illustration, visible signs of Kuchyum's sinfulness - the collection of women and children, the sassy idol standing naked atop his pillar, and the smoke and steam rising from his pot of unclean foods are on display, alerting the observant deity to smite the malefactor. Whether Remezov means to suggest that God is also offended by the Tatars' sartorial choices, the wonderful high-heeled shoes, is not clear, but the drawings are consistent in attributing high heels to Tatar elites, men and women alike, whereas Cossack fighters wear sensible flat boots. ${ }^{25}$

In this image Remezov conveys important information about the interplay between the seen and the unseen. Unnoted in the textual commentary, Kuchyum listens to the whispered advice of a mostly obscured adviser, clean-shaven so perhaps a woman, perhaps an 'evil vizier'. Where, as we have seen, Muscovite grand princes and tsars are shown actively conversing in full and frank discussion with worthy councillors, the Siberian tsar falls into the trap of secretive whisperers, hidden in the shadows. Openness and visibility here stand for political probity and virtue, secretive hiding for sorcery, corruption, and vice.

The upshot of this kind of shady conduct is immediately apparent in the khan's response to the fiery apparitions that foreshadow the Cossacks' arrival and the ultimate Christian victory:

The soothsayers and the captives of one accord foretold to Kuchyum that God would soon give the place to the Christians, and drive him out, and he would come to an evil end. And so it happened. But for this he ordered many to be put to death. ${ }^{26}$

This passage is accompanied by a highly significant illustration, ripe with visual aspersions (Fig. 13). Kuchyum sits regally on his throne, perched on his imperial pillow, wearing his crown. He appears to be engaged in open conversation with the Cossack prisoners who explain to him the obvious and bitter truth about the meaning of the blazing omen. The appearance of forthright exchange is subverted, however, by

\footnotetext{
${ }^{24}$ Remezov (1880 edn); Armstrong (1975: chap. 23).

${ }^{25}$ Harun Yilmaz offers the helpful suggestion that the heels may reflect the nomads' development of the heeled boot necessary for riding with stirrups, a critical technological advance made famous by Lynn White in his classic history of technology (White (1962: 1-38)). The heels may indeed reflect an ethnographic reality of the steppe, but Remezov's choice to feature them in scenes redolent of censure, and particularly scenes of gendered censure, suggests that he imputes more meaning to them than simply neutral reporting.

${ }^{26}$ Remezov (1880 edn); Armstrong (1975: chap. 26).
} 


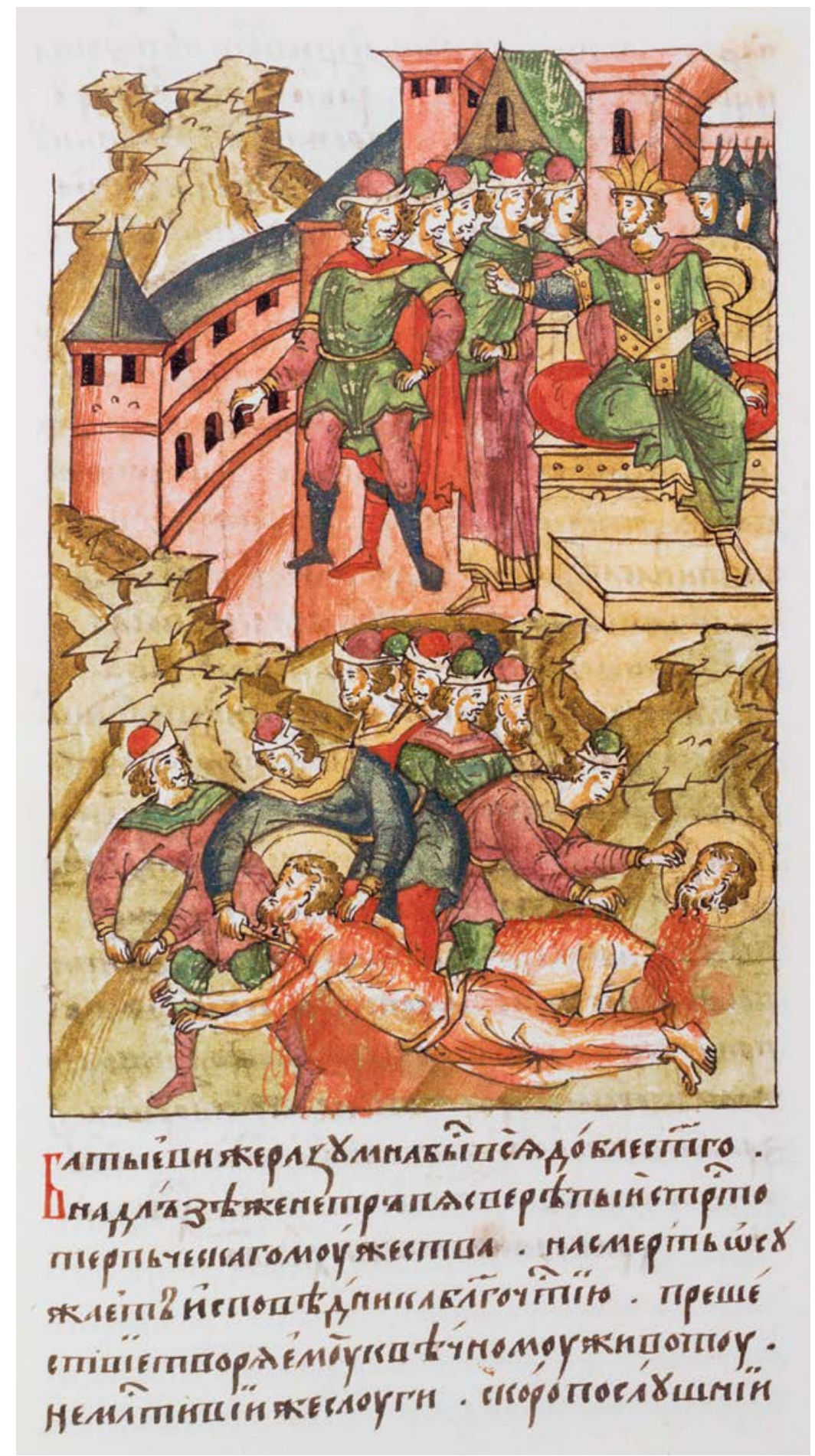

Figure 11. Martyrdom of St Michael of Tver. Kazakova et al. (2014), 6: 97. 


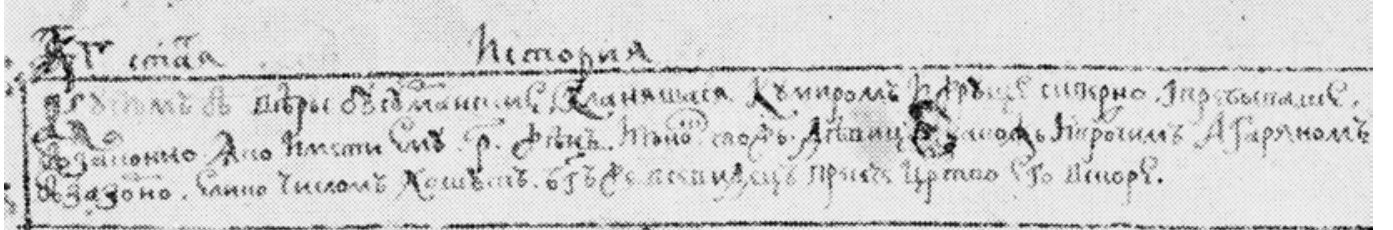
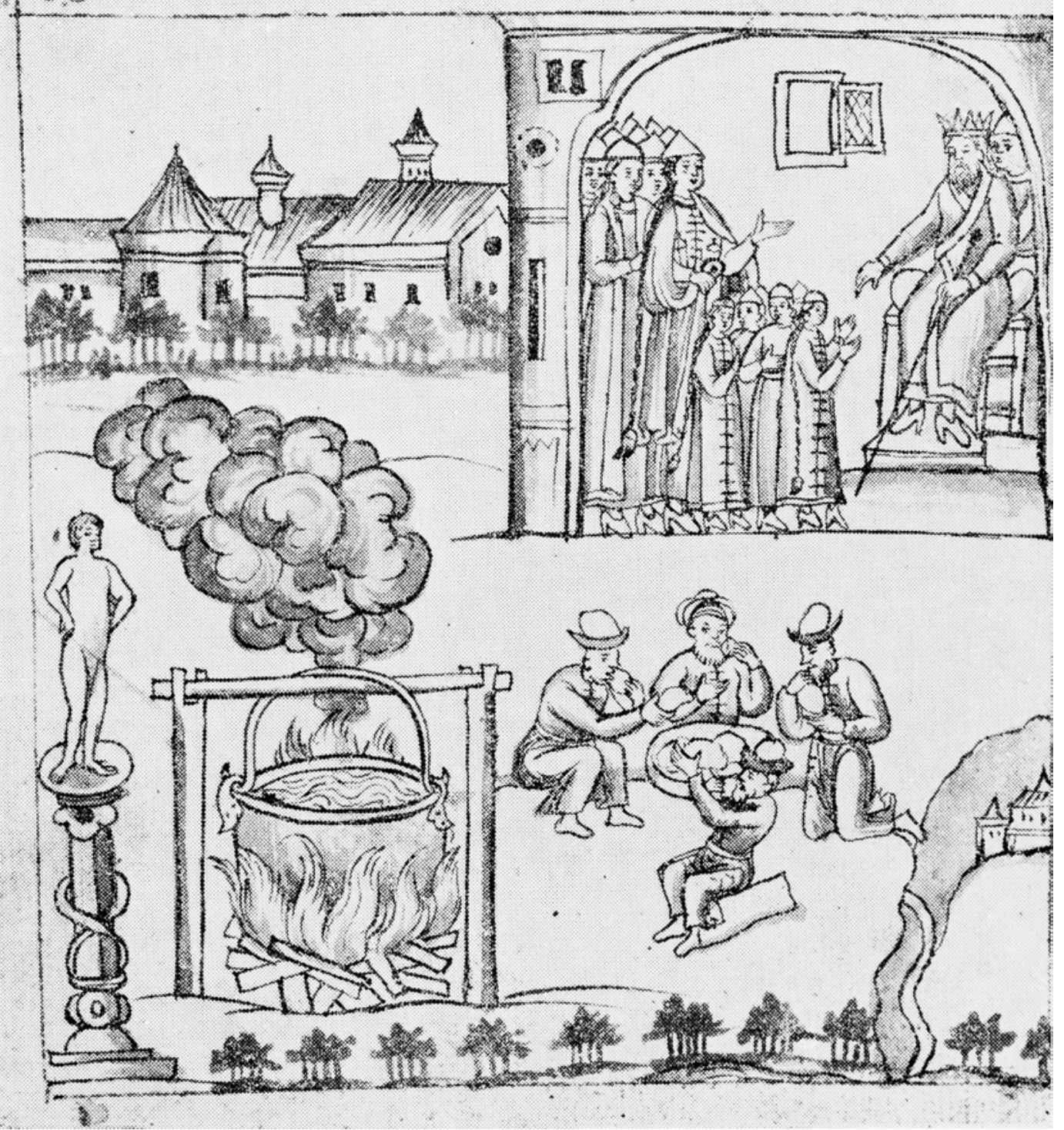

Figure 12. Kuchyum on throne. Remezov (1880 edn), ch. 23. 


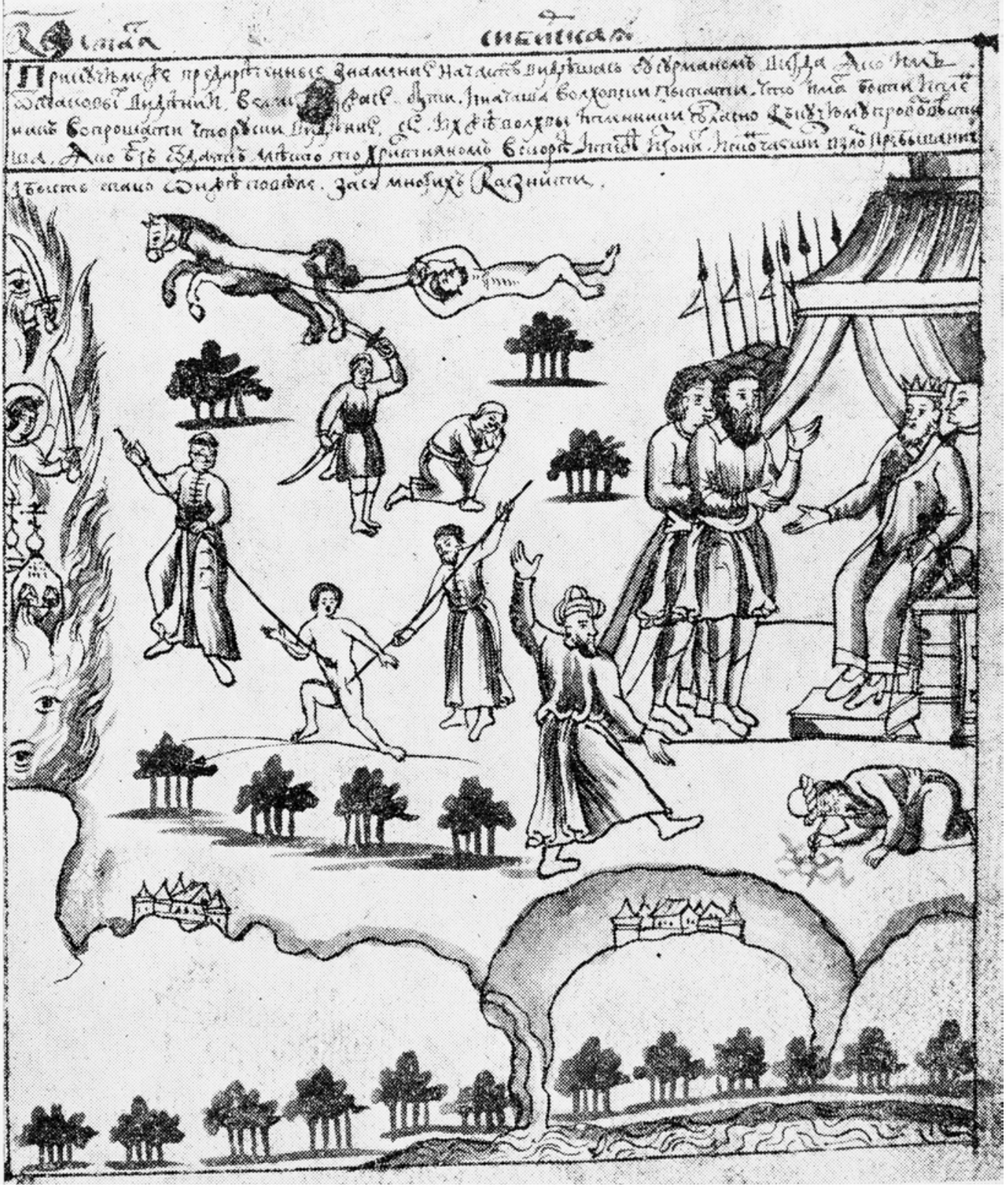

Figure 13. Kuchyum consults with Cossack hostages and soothsayers and then has them executed. Remezov (1880 edn), ch. 26. 
the figure of the closet adviser, obscured in the draperies behind Kuchyum, halfway out of the picture's frame, lips pressed to the khan's ear with whispered perversions. The results we see carried out on the page: for reporting truthfully on the bellicose apparitions that threaten them from the left-hand margin, the truth-tellers, Cossacks and mullahs alike, are brutally tortured and executed: stripped naked and dragged behind horses, stabbed with spears, beheaded.

Kuchyum's injustice, his savage response to the truthful interpretations offered by his wise men and prisoners, is underscored in multiple visual registers. His discussion simulates open, free exchange but it is perverted by his secretive consultation and his deadly response. No formal verdict sanctions these atrocities; rather the absent pointed finger expresses the ruthlessness of Kuchyum's corrupted and fearful rule. Further underscoring the barbarity of his response, his innocent victims are not only cruelly brutalised, but are subjected to the additional violation and humiliation of being stripped naked and fully exposed.

In Remezov's telling, such tyranny took its toll, ultimately undercutting the position of the tyrant himself. The chronicle reports that Yermak's men surged forth for the final battle against Kuchyum in full confidence of their imminent victory: 'Understand this, ye peoples, and submit, for God is with us!' But it was not only God's favour that tipped the balance; it was also the injustice and corruption of Kuchyum's rule. In contrast to the spirited Cossacks, 'the unbelievers' fought reluctantly, with little hope or conviction. 'Driven by Kuchyum, [they] suffered great losses at the hands of the Cossacks, they lamented, fought unwillingly (nevol'no), and died. ${ }^{27}$ Remezov's systematic differentiation between Muscovite just practices of openness and inclusivity and Kuchyum's secretive and cruel tyranny pushes us to attend to Muscovite official verbiage about justice and mercy as these notions were extended from the Russian lands to the most recent imperial dependents.

\section{UNDER THE TSAR'S MIGHTY HAND: MUSCOVITE STRATEGIES OF IMPERIAL INTEGRATION ${ }^{28}$}

As soon as the Cossack vanguard began to consolidate control over the Siberian Tatars, the tsarist regime in all its generosity proclaimed its intention to extend its 'merciful' rule to the new lands. Here 'mercy' assumes a positive valence, seemingly completely at odds with the emphasis on 'merciless' punishment that defines rigorous and scrupulous justice discussed above. Context resolves the apparent contradiction.

\footnotetext{
${ }^{27}$ Remezov (1880 edn); Armstrong (1975: chap. 63).

${ }^{28}$ The phrase is inspired by Nancy Shields Kollmann's discussion of 'Strategies of Integration' within the Russia regions of the tsardom in Kollmann (1999: 169-202).
} 
As we have seen, mercilessness was required to prevent favouritism or corruption from softening a judge's resolve or contaminating an investigation. No misplaced softheartedness should allow malefactors or traitors to escape the full force of the law. Yet, at the same time, mercy played a critical role in legitimising tsarist rule and in mitigating the harshness of social relations. When abject subjects threw themselves on the mercy of their sovereign-protector, religious teachings, political practice, and popular expectation dictated that he should grant it. Indeed, it was his divinely mandated duty to do so. 'Sovereign, tsar, and grand prince, favour me. Have mercy (Gosudar', tsar', i velikii kniaz', pozhalui menia. Smiluisia)' ran the closing line of a standard petition. Supplicants asked not for particular resolutions (punish my rival, let me out of prison, forgive my tax arrears), but rather for the sovereign's open-ended mercy. Appointed by divine selection and entrusted with ruling an Orthodox realm, the tsar answered to no lesser authority than his Creator for the piety and mercifulness of his rule.

From the very earliest phases of conquest, dictates from the centre stated emphatically the need to extend that positive tradition of mercy to the newly incorporated population. The litany of instructions from Moscow insisted that Siberian explorers and officials should deal with the locals 'gently'. The stream of orders continued in subsequent decades and even escalated as Muscovite forces pushed further into the north and east, and as fur-trappers, adventurers, and settlers followed in their wake. Directives underscored the need to 'protect the iasak people' and 'treat them tenderly'. Treating them well and guaranteeing them justice and mercy under the tsar's shielding hand were important, well publicised elements of the Moscow's strategy and vision for imperial control.

In 1599, for instance, the newly crowned tsar Boris Godunov specified that his Siberian officials should don brightly coloured clothes and should assemble the Siberian locals to assure them of his good wishes, his earnest protection, and his desire that they should suffer no need or oppression. The tsar promised, 'that they should live in peace, without fees, in towns or yurts, in provinces and districts'. ${ }^{29}$ The next year, after the celebration of his coronation, the tsar ordered iasak collection to resume as previously but worried that the poor and sick should be exempted, 'so the Siberians do not suffer hardship and so they will not be driven off'. After the collection was complete, the officials were required to 'question the iasak-payers to make sure they were not insulted, mistreated, or oppressed' during the process. ${ }^{30} \mathrm{He}$ insisted that his goal was that 'they should live in peace and quiet . . . and joyously, their fields will bring profit to us'. ${ }^{31}$

\footnotetext{
${ }^{29}$ Miller (1937: 1: 381-2, no. 31).

${ }^{30}$ Miller (1937: 1: 390-2, no. 39).

${ }^{31}$ Miller (1937: 1: 383-4, no. 33). Similar issues are discussed in Bakhrushin (1955a: 216-17).
} 
This was a sensible policy, not just a morally lofty one. Keeping hunters and trappers and farmers on the land would allow the Russians to do well by doing good. It seems fair to assume that the central administration would not send such admonitions repeatedly across enormous distances simply to put a shiny veneer on its military operations. For that matter, since these orders had no element of public display, it is difficult to see how they could have been imagined to serve propagandistic purposes. These were internal orders, not press releases or orchestrated sound bites. They were issued in hope of real policy impact, that their directives would restrain the actions of local operatives.

Remezov's oeuvre suggests that those local operatives, of which he was one, were receptive to these messages. A curious entry in his History of Yermak's Campaign shows the bright light of Russian Orthodox rule illuminating all of Siberia, with, incongruously, a chicken tucked into the bottom left corner (Fig. 14). The intrusion of poultry into a scene of Christian enlightenment is explained by the mostly illegible text: 'Just as a hen gathers its [chicks] under its wing, so shall I . . . my name. ${ }^{\prime 32}$ Drawing in slightly garbled fashion on biblical passages, the metaphor of the hen with its chicks clearly reflects Remezov's acceptance of the party line emanating from the central chancelleries and of the generally shared notions of power and authority that permeated Muscovite society, from Moscow to Okhotsk.

Remezov's work shows that local understanding of the Muscovite mission involved not only spreading a protective wing over the new nestlings, but also preserving them in their traditional ways 'as previously'. Remezov explicitly endorses the policy of protecting local customs in a chapter evidently borrowed from a western philosophical text (Fig. 15). Underneath clouds full of angels, one of whom holds a banner labelled 'Peace' in Old Dutch, a group of men in western dress discuss something with a fellow mysteriously labelled ' 4 ', a remnant copied duly from its lost original. Where he blindly followed his model in the illustration, Remezov actively modified the text to speak to the circumstances in his native land:

Philosophy requires us to preserve justice in all things, through which great love lives among all races, to introduce no innovations, and to send intruders beyond the frontier because we must have care that our Siberian population should live forever. ${ }^{33}$

These are lovely sentiments. As imperial projects go, this sounds like a quite appealing one. Moreover, as the discussion above suggests, they are lent some real substance by

\footnotetext{
${ }^{32}$ Remezov (1880 edn); Armstrong (1975: chap. 1). Matthew 23:37 (also Luke 13:34): 'O Jerusalem, Jerusalem, thou that killest the prophets, and stonest them which are sent unto thee, how often would I have gathered thy children together, even as a hen gathereth her chickens under her wings, and ye would not!' King James Bible 'Authorized Version', Cambridge Edition.

${ }^{33}$ Remezov (1880 edn); Armstrong (1975: chap. 152).
} 


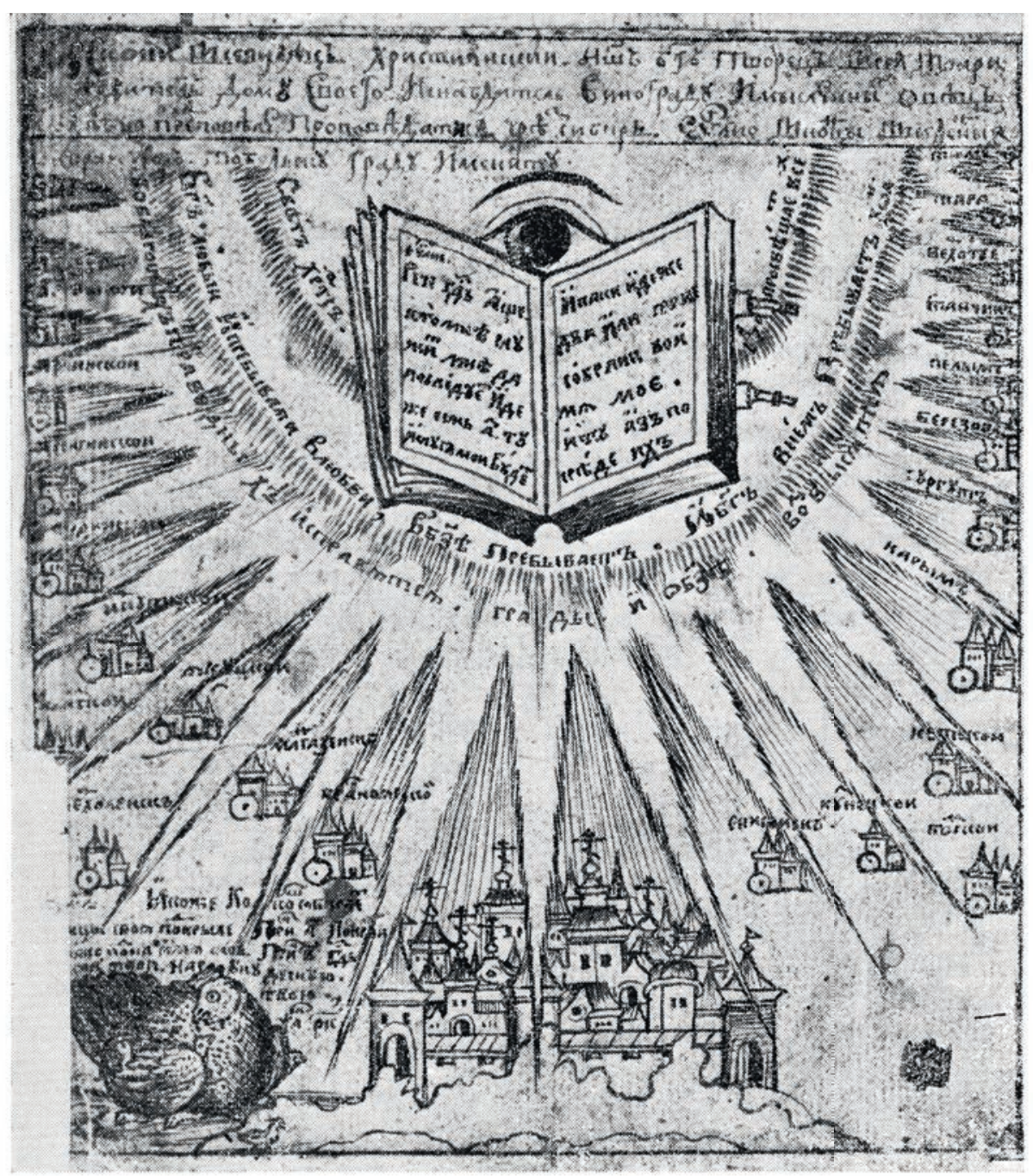

Figure 14. Orthodoxy illuminates Siberia. Remezov (1880 edn), ch. 1.

the evidence that both central officialdom and local agents shared this vision and acknowledged its importance. Indeed, this effort to protect the native populations and preserve their ways of life had a compelling logic for the Muscovites, eager as they were to exploit their new territories' furs and other natural resources. The population on the ground provided the key to gathering those furs, and to the extent that they could be convinced to hand over tribute to their new overlord peaceably and willingly, the job would be so much the easier. 


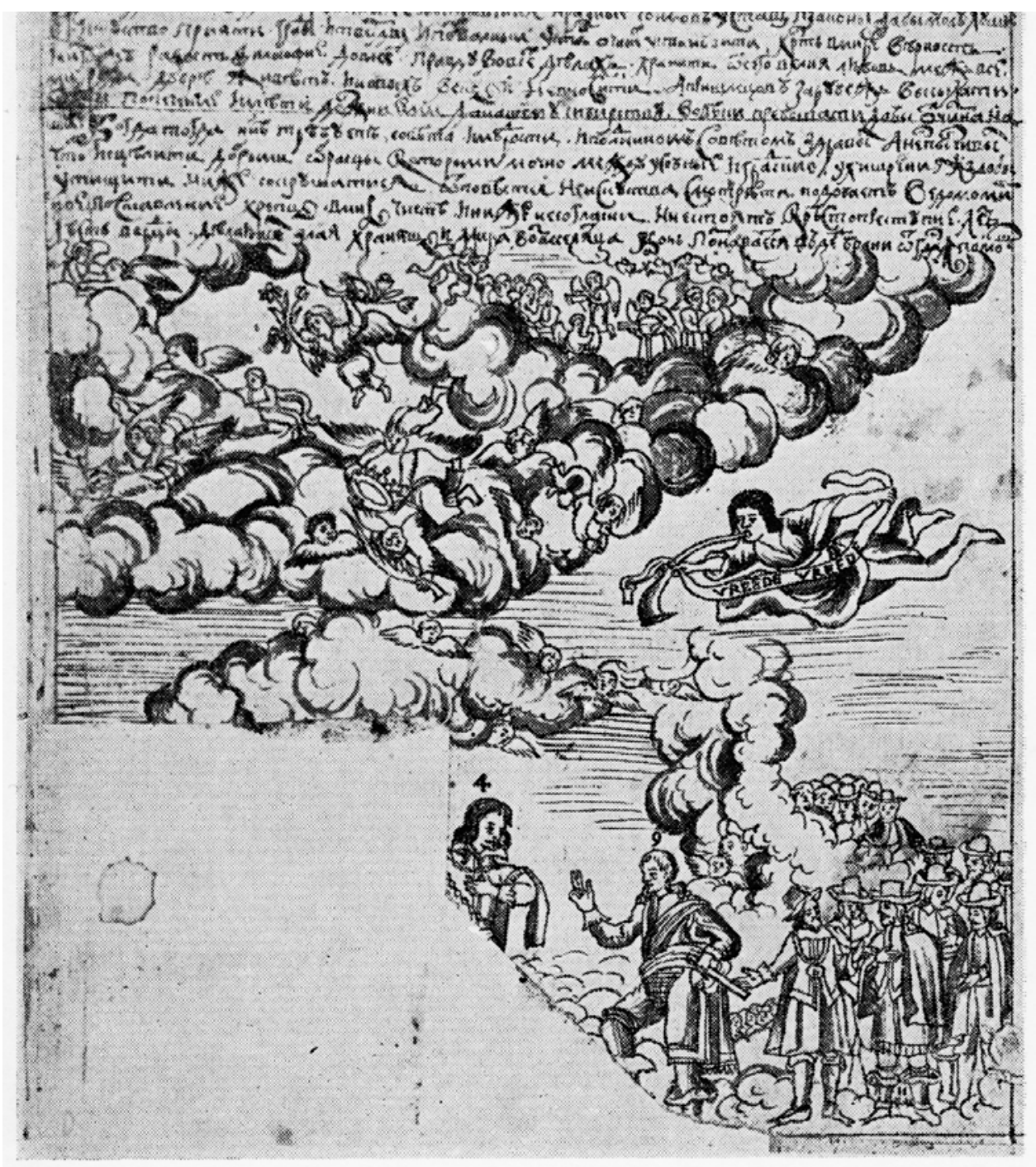

Figure 15. Teachings of philosophy. Remezov (1880 edn), ch. 152.

\section{RIGHTEOUS VIOLENCE AND EXEMPLARY SLAUGHTER}

The grateful chicks and the protective wing, however, obscure crucial and far less appetising pieces of the story. The unapologetic violence we have seen on display in depictions of the early phase of conflict and conquest does not evaporate with the later phases of subjugation and rule. Remezov exposes this other side as well. He pulls aside the curtain to reveal how Yermak's men went about winning loyal, tributepaying subjects for the tsar: 
[They] attacked and captured the stronghold, and hanged many of the best stalwarts by one leg and shot them. And he gathered tribute by his sword which he laid bloody on a table with orders to give a loyal oath of allegiance to the lord tsar to serve him and to pay tribute without fail.... All the natives were seized with terror, and, awed by the threat, not only dared not lift a hand but even to utter a word in the entire Nadtsyn district. (Fig. 16)

Consider all the layers of visual power expressed in this text and image. The chief men hang dead in full view, killed by terrifying 'invisible arrows', as Remezov assures us the locals called the bullets shot from the Cossacks' muskets. The sword lying bloody on the table reinforces the horror and potential for further violence, its threat apparent in both words and image. ${ }^{34}$

In spite of the apparently glaring contradictions inherent in this imperial narrative, a consistent, marvellously Machiavellian logic is at work here. ${ }^{35}$ Remezov, good front-line agent of empire that he was, understood what his sovereign and the Moscow authorities also fully recognised: populations had to be fully and utterly subjugated before they could be integrated into what Nikolaos Chrissidis calls Muscovite 'hierarchies of protection'. Spectacular displays of violence did not have to be repeated frequently, particularly when the tsar's forces were ordered to demonstrate not only the consequences of resistance but also the tangible benefits of submission to the tsar's just demands: 'Seeing that their wives and children were not being killed but treated kindly' by the Cossacks, 'even the rebel Ostyaks were convinced to pay homage with tribute' (Fig. 17). ${ }^{36}$ His illustration shows the Ostyaks lining up to take the sovereign's offer, an offer they couldn't refuse. Coming 'under his mighty hand', they henceforth will acknowledge themselves, in Muscovy's poignant language of political dependency, his 'orphans (siroty)' ${ }^{37}$ Following this logic, Remezov shows time and again how Siberians cede to the inevitable and submit 'voluntarily'. With such grateful compliance, his hero, Yermak, is able to maintain a just peace while enriching himself and his men and filling the tsar's coffers. The chronicle describes how Yermak

\footnotetext{
${ }^{34}$ Remezov (1880 edn); Armstrong (1975: chap. 73); Remezov returned to this episode when he drew a tiny schematic figure of a person hanging by one foot onto a map of the region in one of his great atlases of Siberia: Rossiiskaia natsional'naia biblioteka (RNB) [Russian National Library], St. Petersburg, Ermitazhnoe sobranie, no. 237, Sluzhebnaia chertezhnaia kniga Remezova, 11. 47 ob.-48.

${ }^{35}$ There has been some interesting speculation on whether Machiavelli was read in Muscovy. See Cherniavsky (1968). It seems most unlikely, although Will F. Ryan demonstrates that works in the mode of advice manuals, 'mirrors of princes', did circulate: Ryan (1978).

${ }^{36}$ Remezov (1880 edn); Armstrong (1975: chap. 77, 82).

${ }^{37}$ Muscovites developed an expressive language of dependency that was in common use in all communications with the tsar. Non-elite subjects of the tsar, Russians as well as non-Russians, generally called themselves his orphans. Elites enjoyed the privilege of calling themselves his slaves, kholopy, and women of all ranks used an alternate form of slave, raba. Clergy used the term bogomolets, literally 'one who prays to God'.
} 


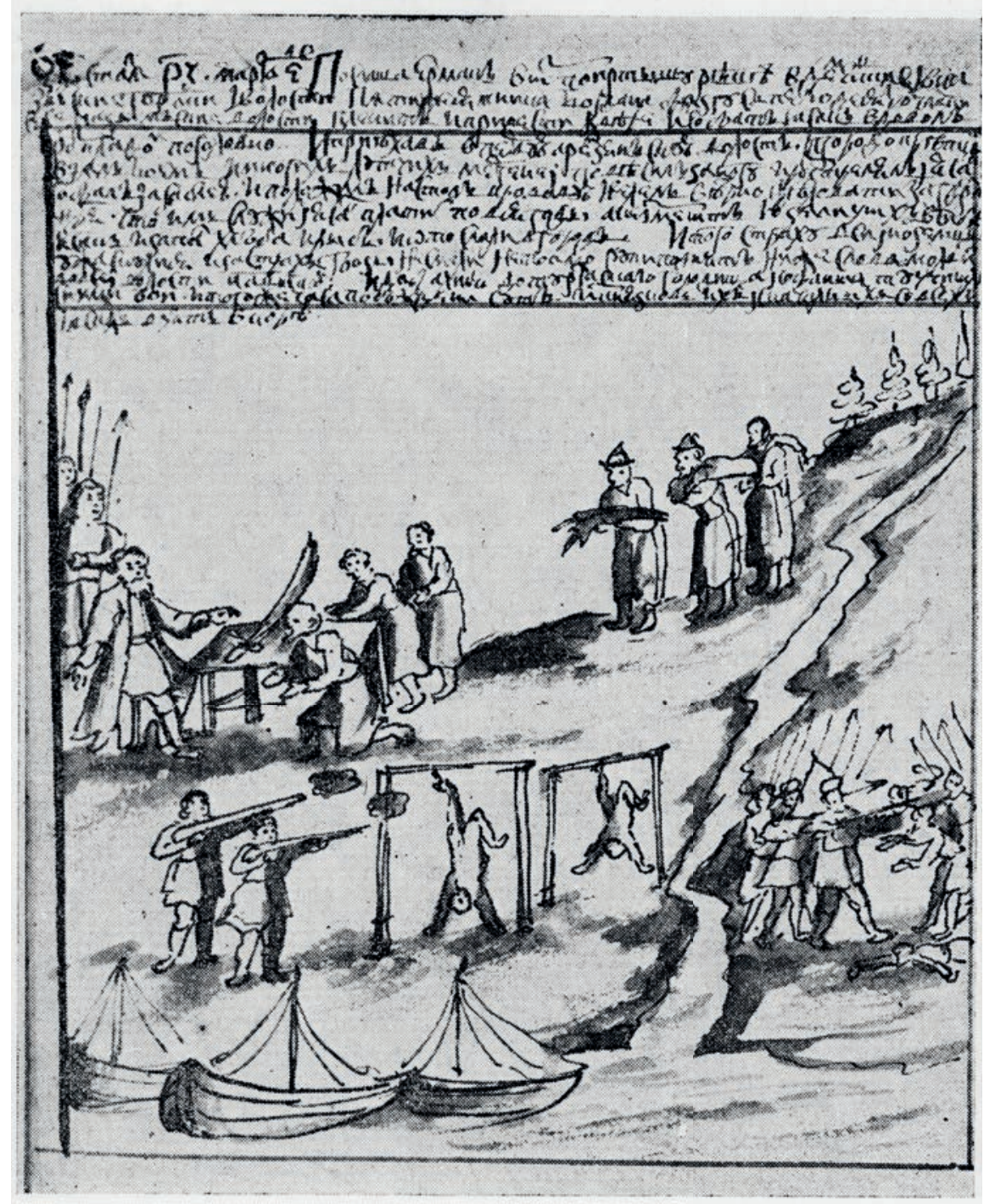

Figure 16. Tribute through terror. Remezov (1880 edn), ch. 73.

levied 'a tribute ... and let . . those who had brought [it] go back to their homes'. ${ }^{38}$ The newly incorporated populations had to be quickly schooled in the principles and expectations that governed political life in the Muscovite centre. Authority rested on and drew its force from a tacit compact, occasionally made explicit: subjects of all ranks owed their paternal lords unquestioning, unconditional, abject submission as

${ }^{38}$ Remezov (1880 edn); Armstrong (1975: chap. 52). 


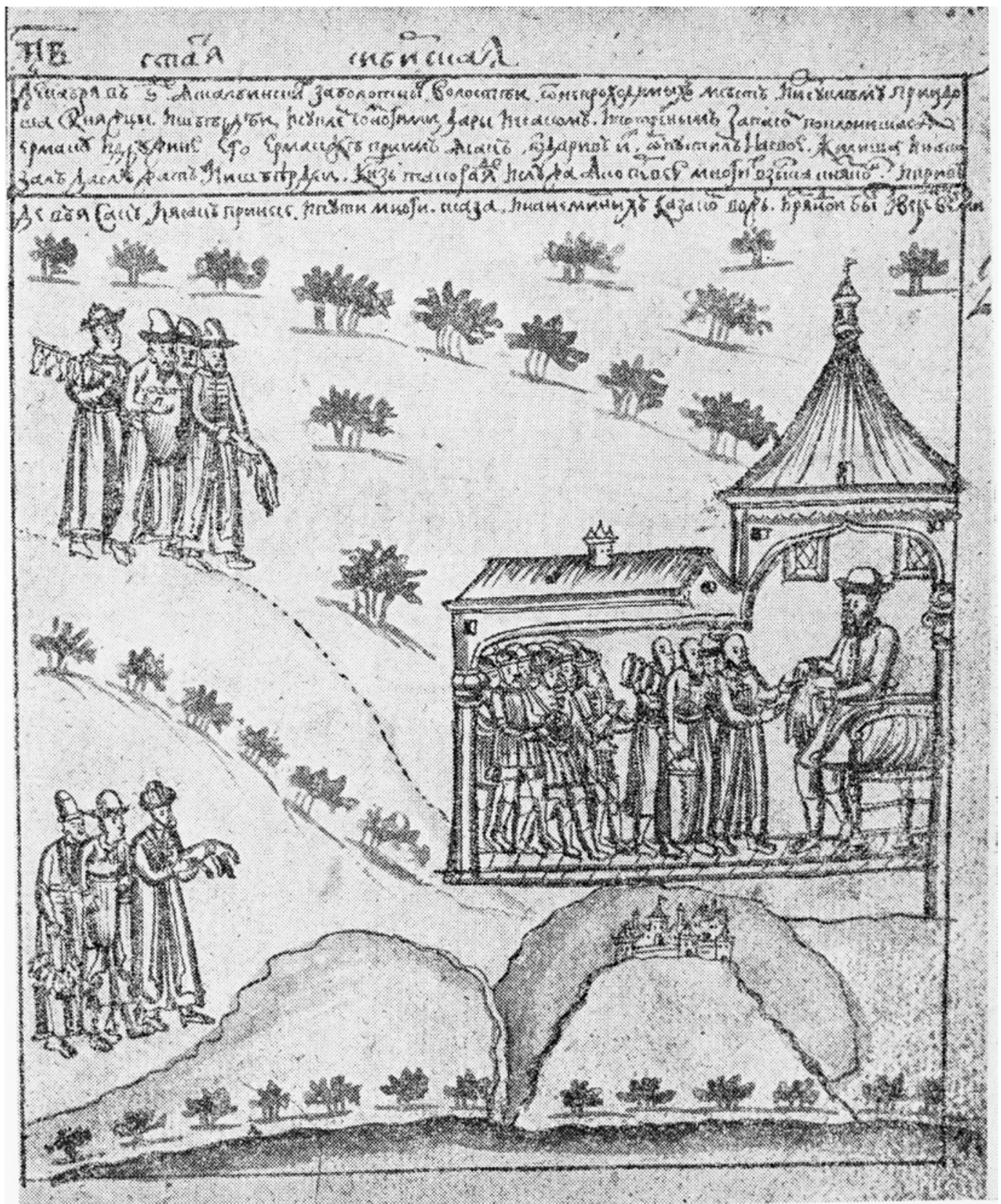

Figure 17. Ostyaks bring tribute. Remezov (1880 edn), ch. 82 . 
his adopted children, his defenceless orphans, and in exchange they should receive protection and stern yet merciful justice.

In spite of the bodies and body parts strewn about the pages, the blooms of blood that flow from those bodies, and explicit and crass profit-motive at work, the Muscovite frontiersmen understood that their hold on their newly subject populations was tenuous at best and that to preserve their conquests, they had to fulfill, at least to some extent, their lofty promises. Once a region was fully conquered and a population recategorised from hostile to pacified (nemirnyi to mirnyi) a new calculus applied. This meant extending the protection of the tsar's stern yet merciful justice to the new peoples, preserving their habits and hunting grounds, leaving them to practise their own forms of religion, and generally celebrating the fact that so many varied 'infidels' kneeled before the tsar and his delegated representatives and, in token of their abject subjugation, came from forest and steppe to offer him their fur in tribute.

\section{THE REALITY QUOTIENT: DID PRACTICE FOLLOW PRINCIPLE?}

These are nice stories, but why should we take all of these convoluted efforts to differentiate virtuous, pious Christian slaughter from ruthless, tyrannical, pagan slaughter? Why should we grant them any more analytical status than any other propagandistic campaign to whitewash the home team while smearing the other?

We should for several reasons. First, because it mattered to them, to the diplomats and political authorities in Moscow, to the governors and Cossacks in Siberia, and to the artists and chroniclers whose works convey these morality tales. As we have seen, illustrators devoted a great deal of time and attention to getting the visual semiotics right. These various artists, plying their craft across more than a century and across thousands of miles of tsarist terrain, worked out a careful symbolic code to distinguish tyranny from righteous sovereignty.

But second, we have some quite interesting evidence that this framing narrative actually had some effect on the real-life experiences of empire for those most deeply and immediately affected: the indigenous Siberians. Taking the sovereign up on his promises, Siberian reindeer herders and dog-sledders turned to the Russian courts in significant numbers, asserting their right to receive protective justice. They pinned their hopes on the courts to resolve internal conflicts with their fellow Siberians and also to resolve disputes with encroaching or bullying Cossacks and Russians. In both of these instances, it is remarkable that indigenous hunters and trappers felt it worth their while to use tsarist courts, that they felt they could hope for fair hearings and just outcomes from these alien institutions with Russian officials presiding over them. And yet they did so, presumably going to considerable trouble and expense to find 
cultural mediators who could translate their complaints into the language and format expected in a Muscovite court. ${ }^{39}$

Equally surprising, their hopes were not entirely misplaced. Military reports and various documentary sources describe flagrant brutality on the part of Muscovite operatives. Like the merciless Muscovite swordsmen depicted so proudly in the Litsevoi svod, Muscovite conquerors, explorers, trappers, and iasak-collectors carried out their jobs with gusto. At their hands, entire settlements were slaughtered, villages brutalised, old people and shamans beaten, men, women, and children abducted and enslaved. Demands for fur drove tribute payers to overtrap their territories and deplete the fur-bearing animals. Russian settlement impinged on indigenous patterns of movement across the terrain and obstructed animals' migration routes. Disruption and violence were everywhere apparent. ${ }^{40}$ Yet, strikingly, we know of many of these atrocities precisely because someone protested. Many of these cases entered the archival record because someone, whether a higher-up in the chain of command, an embittered underling, or a native survivor, sounded an alarm, flagging these actions as violations.

Official hearings not infrequently upheld the claims of aggrieved locals, even when lodged against Russians or Cossacks of impressive stature. Notably, a suit brought against Vladimir Atlasov, one of the most celebrated of conqueror-explorers of the frozen Arctic, charged him and a fellow Cossack with brutalising a community in Yakutsk. 'They came to my family's yurt', wrote an aggrieved victim, 'and beat my father and my brothers and my relatives and maimed them. They tortured them. They tied their hands behind their backs and tied them to the woodpile and out of insatiable greed stamped on their chests and beat them and stole everything possible by force.' The case was heard in 1688, and the court sided with the Yakuts. 'By order of the Great Sovereign and in accordance with the natives' petitions, the Cossacks Volodka and Mishka will be punished for their criminality and troublemaking and violence and injury and destruction. Tie Volodka to the stocks and beat him mercilessly with a knout. . . Take signed security documents for both of them, guaranteeing that they won't make trouble and rebellious mischief in the future. ${ }^{41}$

Native Siberians' use of the courts had a visual component as well. Their petitions infused standard Muscovite official forms with traces of local visual practices. A petition from a Yakut herdsman, complaining to the tsar's representative that some other Yakuts had stolen and killed his cow, exemplifies this fusion. The petition fully matches

\footnotetext{
${ }^{39}$ Kivelson (2006: 194-209).

${ }^{40}$ For instance, see discussions in Bakhrushin (1955b); Ogorodnikov (1922); Ogryzko (1941); Slezkine (1996: 11-46).

${ }^{41}$ Al'kor and Grekov (1936: no. 138).
} 
the form and appearance of any petition submitted to the tsar from any of his Russian subjects, so clearly the document was written by some kind of intermediary, a cultural and linguistic translator and scribe. The case was duly heard and registered, and the sovereign's justice administered, in this case, with all the parties being released to their homes. Most remarkable in this case, the Yakuts signed the document with their 'marks', visibly inscribing themselves in the tsarist system of justice, claiming their rights to paternal protection as subjects and 'orphans', of the tsar (Fig. 18). ${ }^{42}$

More startling still is another document of similar ilk from the year 1660 . Again, the document contains the petition on the front and the signature mark, this time of a Iukagir 'princeling (kniazets)' named Chokcha from the Anadyr River, on the back (Fig. 19). This suit was brought against two Cossacks. What is truly breathtaking is the identity of one of the two Cossacks: Semen Dezhnev. Dezhnev, mentioned at the start of this article as one of the great explorers of the

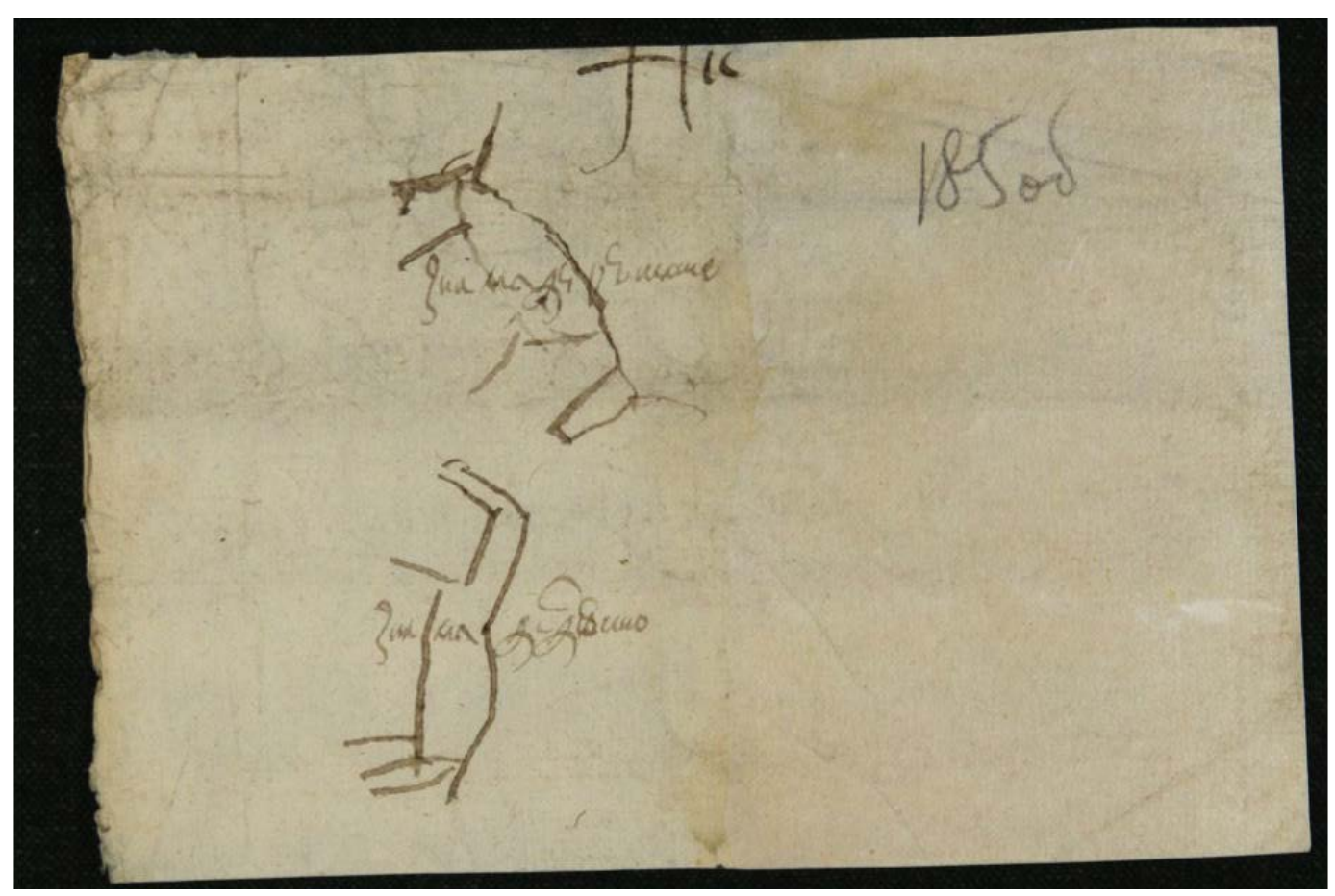

Figure 18. Yakut signatures. Rossiiskii Gosudarstvennyi Arkhiv Drevnikh Aktov (RGADA), [Russian State Archive of Ancient Documents], Moscow, f. 1177 Iakutskaia prikaznaia izba, op. 1l, e. khr. 12, 1. 185ob.

\footnotetext{
${ }^{42}$ Rossiiskii Gosudarstvennyi Arkhiv Drevnikh Aktov (RGADA), [Russian State Archive of Ancient Documents], Moscow, f. 1177 Iakutskaia prikaznaia izba, op. 1, e. khr. 12, 11. 183-5ob.
} 


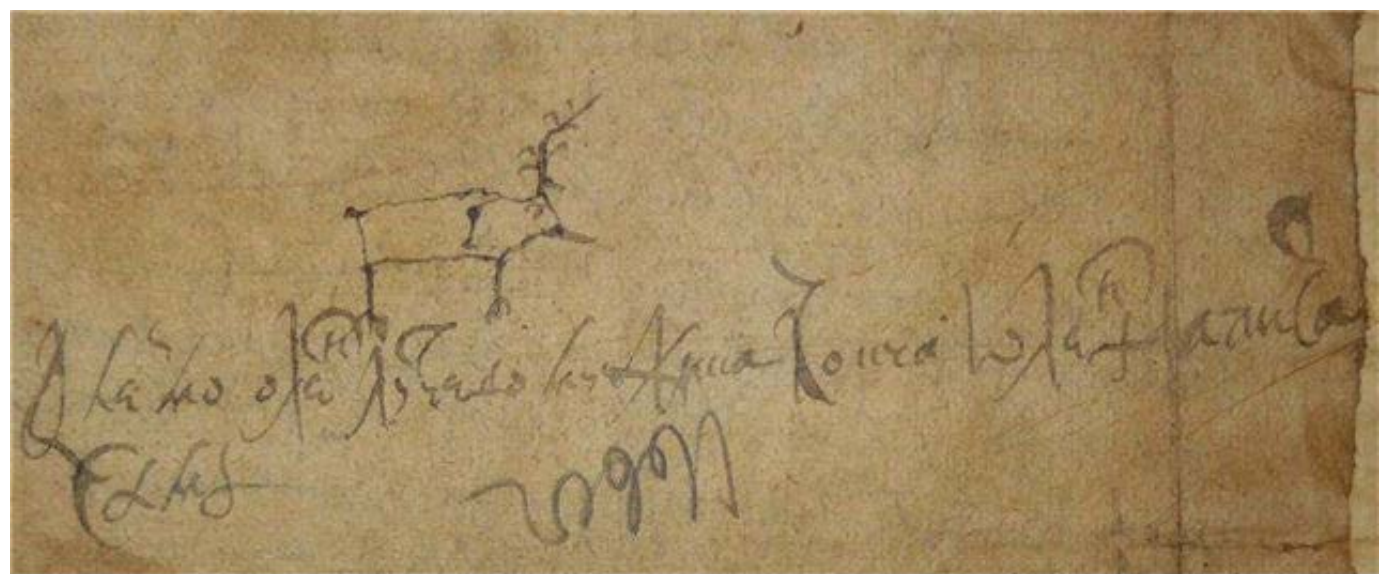

Figure 19. Yukagir signature. Rossiiskii Gosudarstvennyi Arkhiv Drevnikh Aktov (RGADA), [Russian State Archive of Ancient Documents], Moscow, f. 1177 Iakutskaia prikaznaia izba, document number not found.

Russian Pacific, enjoys a reputation as a towering figure of Russia's Arctic exploration. Yet this grand hero was brought to task for abusing the Iukagirs, and their leader imprinted his mark and his claim to tsarist protection with his reindeer sign, a claim the court officials evidently took seriously by registering the case and preserving the documents in the archives. ${ }^{43}$

\section{CONCLUSION}

To the dead, the mutilated, the displaced and desperate, the virtue inherent in the tsar's raised finger or his open-handed consultation no doubt made little difference. From their vantage point, the picture was surely a dark one. To the warriors, bureaucrats, and Cossack frontiersmen who manned the Muscovite advance, however, these fine distinctions mattered a great deal. The publicists of empire-the ranks of illustrators engaged in compiling the Litsevoi svod; Semen Remezov labouring in his workshop in Siberia - worked in certainty that they were serving a legitimate sovereign who protected his subjects old and new through the justice and mercy of formal law. The henchmen of empire, brutes like Dezhnev and Atlasov, found themselves face to face with the cogent logic of their sovereigns' imperial claims. And, once the carnage

\footnotetext{
${ }^{43}$ Ibid., f. 1177 (archival number not yet found). Document posted at: http://www.balto-slavica.com/ forum/lofiversion/index.php/t1327-100.html http://dankovkazak.livejournal.com/ (viewed 6 November 2014). Description on this site says the complaint named Semen Dezhnev and Ivan Saldat. I have yet to find the document and so have been unable to confirm this.
} 
of conquest was over, this same narrative of protection and justice served to lure at least some of the tsars' new subjects into and to hold them in a complex relationship with imperial power.

Ultimately, this imagery of conquest and control suggests that to the people of the tsar's empire, Muscovy was not, as generations of outside observers have maintained, a lawless society governed by arbitrary whim. From the internal perspective, it was not at all the 'savage soyle', that the Englishman George Turberville described in his late6th-century verse, "where lawes doe beare no sway/But all is at the King his wil, to save or els to slay'. ${ }^{44}$ Rather, they proudly distinguished their ruler from the despots of the steppe because of his inclusive consultation, his stern yet merciful administration of righteous justice, and his capacious, encompassing protection. Counterintuitive though it seems, these propagandistic images of Muscovy may well have translated into concrete policies and practices of imperial rule, leading to meagre but palpable benefits for the conquered and subjugated peoples of the tsar's empire.

Acknowledgements: I would like to express my gratitude to Hamish Scott and the British Academy for the invitation to speak and to publish this work and to all those who offered suggestions after my talk. Thanks are due to Nancy Shields Kollmann for inspiration and permission to cite her unpublished work. I am also grateful to Gábor Czoch and László Kontler and the participants in the TEMA seminar at Central European University and Eötvös Loránd University in Budapest and Malte Griesse and the participants at the Harvard workshop on 'Visualizing revolt and punishment in early modern times', for their suggestions and comments.

\section{REFERENCES}

Al'kor, Ia.P., \& Grekov, B.D. (eds) (1936), Kolonial'naia politika Moskovskogo gosudarstva v Iakutii XVII v. Sbornik dokumentov (Leningrad, Institut narodov Severa TsIK SSSR).

Armstrong, Terence (ed.) (1975), Yermak's Campaign in Siberia: A Selection of Documents Translated from the Russian Chronicles by Tatiana Minorsky and David Wileman (London, Hakluyt Society).

Arnold, Yanina (2014), 'Writing Justice: Fiction and Literary Lawyers in Late Imperial Russia, 1864-1900' (Ph.D. dissertation, Ann Arbor, The University of Michigan).

Bakhrushin, S.V. (1955a), 'Sibirskie slobodchiki (iz istorii kolonizatsii Sibiri)', in his Nauchnye trudy, vol. 3, Izbrannye raboty po istorii Sibiri XVI-XVII vv., part 1: Voprosy russkoi kolonizatsii Sibiri v $X V I-X V I I$ vv. (Moscow, Nauka).

Bakhrushin, S.V. (1955b), Nauchnye trudy, vol. 3: Izbrannye raboty po istorii Sibiri XVI-XVII vv., part 2, Istoriia narodov Sibiri v XVI-XVII vv. (Moscow, Nauka).

${ }^{44}$ Turberville (1977 edn: 442). Quoted and discussed in Palmer (1995: 329-30). This trope is discussed in Poe (2001). 
Burbank, Jane (2004), Russian Peasants Go to Court: Legal Culture in the Countryside, 1905-1917 (Bloomington, Indiana University Press).

Cherniavsky, Michael (1968), 'Ivan the Terrible as Renaissance Prince', Slavic Review 27: 195-211. http://dx.doi.org/10.2307/2493710

Dmytryshyn, Basil, Crownhart-Vaughan, E.A.P. \& Vaughn, Thomas (eds) (1985), Russia's Conquest of Siberia, 1558-1700: To Siberia and Russian America: Three Centuries of Russian Eastward Expansion, vol. 1, A Documentary Record (Portland, Oregon Historical Press).

Gol'denberg, Leonid A. (1965), Semen Ul'ianovich Remezov, sibirskii kartograf i geograf, 1642-posle 1720 gg. (Moscow, Nauka).

Gol'denberg, Leonid A. (1991), Izograf zemli sibirskoi (Magadan, Magadanskoe knizhnoe izdatel'stvo).

Gruber, Isaiah (2012), Orthodox Russia in Crisis: Church and Nation in the Time of Troubles (DeKalb, IL, Northern Illinois University Press).

Kazakova, E.N. et al. (eds) (2009-14), Litsevoi letopisnyi svod XVI veka, 38 vols (Moscow, AKTEON). Available online at: http://akteon.cld.bz/LLS (viewed 22 February 2015).

King James Bible 'Authorized Version', Cambridge Edition.

Kivelson, Valerie (2006), Cartographies of Tsardom: The Land and Its Meanings in Seventeenth-Century Russia (Ithaca, NY, Cornell University Press).

Kivelson, Valerie (2013), Desperate Magic: The Moral Economy of Witchcraft in Seventeenth-Century Russia (Ithaca, NY, Cornell University Press).

Kollmann, Nancy Shields (1999), By Honor Bound: State and Society in Early Modern Russia (Ithaca, NY, Cornell University Press). http://dx.doi.org/10.1017/CBO9781139177535

Kollmann, Nancy Shields (2012), Crime and Punishment in Early Modern Russia (Cambridge, Cambridge University Press).

Kollmann, Nancy Shields (forthcoming), 'Representing legitimacy in Early Modern Russia', Russian Review.

Lantzeff, George V. (1943), Siberia in the Seventeenth Century: A Study of the Colonial Administration (Berkeley, University of California Press).

Lincoln, Bruce W. (1994), The Conquest of a Continent: Siberia and the Russians (New York, Random House).

Martin, Russell E. (2012), A Bride for the Tsar: Bride-Shows and Marriage Politics in Early Modern Russia (DeKalb, IL., Northern Illinois University Press).

Michels, Georg (2003), 'Ruling without Mercy: Seventeenth-Century Russian Bishops and their Officials', Kritika, 4: 515-42. http://dx.doi.org/10.1353/kri.2003.0044

Miller, G.F., Istoriia Sibiri (1937, 1941), 2 vols (Moscow and Leningrad, Nauka).

Ogorodnikov, V.I. (1922), Iz istorii pokoreniia Sibiri: Pokorenie Iukagirskoi zemli (Chita: n.p.).

Ogryzko, I.I. (1941), Khristianizatsiia narodov Tobol'skogo severa v XVIII v. (Leningrad, Leningradskoe otdelenie Uchebno-Pedagogicheskogo izdatel'stva Narkomprosa RSFSR).

Palmer, Daryl W. (1995), 'Jacobean Muscovites: Winter, Tyranny, and Knowledge in The Winter's Tale', Shakespeare Quarterly, 46: 323-39. http://dx.doi.org/10.2307/2871121

Poe, Marshall (2001), A People Born to Slavery: Russia in Early Modern European Ethnography, 1476-1748 (Ithaca, NY, Cornell University Press).

Popov, G. (1993), Tver Icons, 13th-17th Centuries (St Petersburg, Aurora Art Publishers).

Purchas, Samuel (1906), Purchas His Pilgrimes, 20 vols (Glasgow, James MacLehose).

Remezov, S.U. (1880 edn), Kratkaia sibirskaia letopis' (Kungurskaia) so 154 risunkami, ed. A.I. Zos (St. Petersburg, Tipografiia F.G. Eleonskago).

Rossiiskaia natsional'naia biblioteka (RNB) [Russian National Library], St. Petersburg, Ermitazhnoe sobranie, no. 237, Sluzhebnaia chertezhnaia kniga Remezova, 11. 47 ob.-48.

Rossiiskii Gosudarstvennyi Arkhiv Drevnikh Aktov (RGADA), [Russian State Archive of Ancient Documents], Moscow, f. 1177 Iakutskaia prikaznaia izba, op. 1, e. khr. 12, 11. 183-5ob. [and 
another document, archival number not yet found. Document posted at: http://www.balto-slavica. com/forum/lofiversion/index.php/t1327-100.html http://dankovkazak.livejournal.com/ (viewed 6 November 2014)].

Ryan, Will F. (1978), 'The Old Russian Version of the Pseudo-Aristotelian Secreta Secretorum', Slavonic and East European Review, 56: 242-60.

Sankt-Peterburgskii Institut Istorii RAN (SPbII RAN) [St Petersburg Institute of History of the Russian Academy of Science, St Petersburg], 'Nakaz Vladimirtsev vybrannomu imi iz svoei sredy dvorianinu ...' (June 28, 1648), sobranie A.M. Artem'eva, no. 2.

Slezkine, Yuri (1996), Arctic Mirrors: Russia and the Small Peoples of the North (Ithaca, NY, Cornell University Press).

Turberville, George (1977), 'The Author Being in Moscovia', Epitaphes, Epigrams, Songs and Sonets (1567) and Epitaphes and Sonnettes (1576), intro. Richard J. Panofsky (Delmar, NY, Scholars' Facsimiles and Reprints).

Weickardt, George (1992), 'Due Process and Equal Justice in the Muscovite Codes', Russian Review, 51: 463-80. http://dx.doi.org/10.2307/131040

White, Lynn (1962), Medieval Technology and Social Change (Oxford, Oxford University Press).

Wood, Alan (ed.) (1991), The History of Siberia: From Russian Conquest to Revolution (London, Routledge).

Wortman, Richard S. (1976), The Development of a Russian Legal Consciousness (Chicago, Chicago University Press). http://dx.doi.org/10.7208/chicago/9780226907772.001.0001

The author: Valerie Kivelson is Thomas N. Tentler Collegiate Professor and Arthur F. Thurnau Professor of History at the University of Michigan, Ann Arbor. Her books include Desperate Magic: The Moral Economy of Witchcraft in Seventeenth-Century Russia (Cornell, 2013), and Cartographies of Tsardom: The Land and Its Meanings in Seventeenth-Century Russia (Cornell, 2006). She has edited several collections, including Witchcraft Casebook: Magic in Russia, Poland, and Ukraine, 15th-21st Centuries, Russian History/Histoire russe vol. 40, nos. 3-4 (2013) and Picturing Russia: Explorations in Visual Culture, with Joan Neuberger (Yale, 2008).

vkivelso@umich.edu

To cite the article: Valerie A. Kivelson (2015), 'Rivers of blood: Illustrating violence and virtue in Russia's early modern empire', Journal of the British Academy, 3: 69-105. DOI $10.85871 /$ jba/003.0069

This article is licensed under a

Creative Commons Attribution-NonCommercial-NoDerivs 3.0 Unported License.

Journal of the British Academy (ISSN 2052-7217) is published by

The British Academy - the national academy for the humanities and social sciences.

10-11 Carlton House Terrace, London, SW1Y 5AH

www.britishacademy.ac.uk 
